IZA DP No. 7686

Criminal Victims, Victimized Criminals, or Both? A Deeper Look at the Victim-Offender Overlap

Horst Entorf

October 2013 


\title{
Criminal Victims, Victimized Criminals, or Both? A Deeper Look at the Victim-Offender Overlap
}

\author{
Horst Entorf \\ Goethe-University Frankfurt \\ and IZA
}

Discussion Paper No. 7686

October 2013

\author{
IZA \\ P.O. Box 7240 \\ 53072 Bonn \\ Germany \\ Phone: +49-228-3894-0 \\ Fax: +49-228-3894-180 \\ E-mail: iza@iza.org
}

\begin{abstract}
Any opinions expressed here are those of the author(s) and not those of IZA. Research published in this series may include views on policy, but the institute itself takes no institutional policy positions. The IZA research network is committed to the IZA Guiding Principles of Research Integrity.

The Institute for the Study of Labor (IZA) in Bonn is a local and virtual international research center and a place of communication between science, politics and business. IZA is an independent nonprofit organization supported by Deutsche Post Foundation. The center is associated with the University of Bonn and offers a stimulating research environment through its international network, workshops and conferences, data service, project support, research visits and doctoral program. IZA engages in (i) original and internationally competitive research in all fields of labor economics, (ii) development of policy concepts, and (iii) dissemination of research results and concepts to the interested public.
\end{abstract}

IZA Discussion Papers often represent preliminary work and are circulated to encourage discussion. Citation of such a paper should account for its provisional character. A revised version may be available directly from the author. 


\section{ABSTRACT \\ Criminal Victims, Victimized Criminals, or Both? A Deeper Look at the Victim-Offender Overlap ${ }^{1}$}

Offenders are more likely than non-offenders to be victims, and victims are more likely than non-victims to be offenders. The overlap between offenders and victims is not well understood in criminology, and in the economics of crime the stylized empirical fact is even widely ignored. The paper gives a survey of leading theoretical interpretations and empirical results. It summarizes findings from criminology and focuses on economic explanations, where rational choice, behavioral economics, as well as bounded and ecological rationality are discussed. The paper presents new econometric evidence based on German survey data covering victimization experiences and criminal activities. Using recursive bivariate Probit modeling, econometric results confirm that victimization depends on offending but not vice versa. Among the joint covariates of the bivariate system, broken homes, criminal records of parents and personal indebtedness turn out as highly relevant factors of offending behavior, whereas individual victimization risks are significantly linked to education, employment and size of peer groups.

JEL Classification: C35, C25, J12, K42, Z13

Keywords: victim-offender overlap, crime, victimization, rational choice, behavioral economics, negative reciprocity, recursive bivariate probit, education and victimization, indebtedness

Corresponding author:

Horst Entorf

Goethe University Frankfurt

RuW, Postbox 48

Grueneburgplatz 1

60323 Frankfurt am Main

Germany

E-mail: entorf@wiwi.uni-frankfurt.de

\footnotetext{
${ }^{1}$ Earlier versions of the paper have been presented at the Conference on Retaliation, MPI for Foreign and International Criminal Law, Freiburg, the $4^{\text {th }}$ Annual IZA Meeting on the Economics of Risky Behavior in Istanbul, $4^{\text {th }}$ Transatlantic Workshop on the Economics of Crime in Rotterdam, the German Economic Association Conference in Goettingen, and economic seminars at FU Berlin, Marburg University and St. Gall. I thank seminar participants, in particular Christian Dustmann, Bernd Fitzenberger, Susan Laury, Stephen Machin, Viktor Steiner, Erdal Tekin, Christian Traxler, Thomas Tripp, and Robert Wright for helpful comments and suggestions on previous versions of this paper.
} 


\section{Introduction}

The overlap between offenders and victims has been well documented since the early contributions by von Hentig (1941, 1948) and Wolfgang (1958). Prominent criminological explanations are given by routine activity/lifestyle theories (e.g. Cohen and Felson 1979), the subculture-of-violence approach (Singer 1981), and low-self control (Gottfredson and Hirschi 1990). The empirical stylized fact is much less recognized in the field of economics of crime. This is somewhat surprising as behavioral economics might provide an important link between offending and victimization. In particular, the concept of 'negative reciprocity' (Fehr and Gächter 2000, 2002) and elements of bounded rationality such as 'anger' are potential key factors in theoretical explanations of the victim-offender overlap.

The article gives a survey of leading theoretical criminological explanations such as routine activity and low self control and has a focus on economic interpretations. The paper discusses approaches based on traditional economic reasoning and modern behavioral economics. We contrast classical rational choice behavior with 'irrational' impulsive retaliatory behavior, which, according to economic psychology, can even be considered as 'rational' crime deterrent (Van Winden and Ash 2012) or as "ecologically rational" behavior (Frank 1988, Gigerenzer 2005). The paper also includes a survey of empirical results found in the criminological and economic literature. Econometric studies are rare, though. Whereas Jennings et al. (2012) review 37 criminological studies spanning over five decades (1958-2011), to the best knowledge of the author only Deadman and MacDonald (2004) and Foreman-Peck and Moore (2010) are authors related to the economics of crime. ${ }^{2}$

Our own econometric contribution improves upon the existing literature by providing a thorough analysis of the bivariate interactions between offending and victimization using survey data on the German resident population. These data are particularly suited for our purposes, since they include information concerning individual, family and peer group characteristics, and they are not limited to adolescents or deprived subgroups of the population (as is the case in most criminological studies, see Jenkins et al. 2012). Moreover, applied recursive bivariate Probit analysis extends previous research based on similar bivariate Probit modelling (Deadman and MacDonald 2004, Foreman-Peck and Moore 2010, Silver et al. $2011)$.

\footnotetext{
${ }^{2}$ A further notable exception is Fajnzylber et al. (2000), but their focus is on aggregate data. They analyze the correlation between crime and victimization rates using country data.
} 
Results confirm that offending and victimization are subject to common unobserved factors. Econometric findings further indicate that offending and victimization are partly affected by common observable factors such as educational and parental background, but they are also influenced by specific aspects such as "health condition" (for victimization) or gender (for offending). Among the economic factors, personal indebtedness is something which is rarely studied in economics of crime modeling (McIntyre and Lacombe, 2012, is a notable exception). We find that excessive personal debt is associated with a higher propensity of committing crimes (and has no significant link to victimization). The status of unemployment has no effect on offending, but individuals who report being employed show higher risk of victimization than unemployed people. Likewise, the victimization rate of better educated respondents exceeds the one of less educated survey participants. As the bulk of victimization is related to property crimes, the results can be interpreted by rational offenders who prefer lucrative targets to less attractive victims. As regards the mutual interdependence of offending and victimization, recursive bivariate Probit analysis suggests endogeneity of victimization, whereas victimization experiences are insignificant for criminal behavior once "familial transmissions of criminal convictions" (Rowe and Farrington 1997, see also Hjalmarsson and Lindquist 2012) have been controlled for.

This paper is organized as follows. Chapter 2 gives a brief survey on theoretical considerations in criminology, economics and other fields. Chapter 3 presents empirical results found in the literature. The data description can be found in Chapter 4. In Chapter 5, econometric results are presented and discussed. Chapter 5 concludes.

\section{Understanding the Victim-Offender Overlap}

\section{Linking offending and victimization: Basic criminological explanations}

Offenders are more likely than non-offenders to be victims, and victims are more likely than non-victims to be offenders. ${ }^{3}$ For more than 60 years, the overlap between offenders and victims has been documented in the criminological literature (see von Hentig 1941, 1948, Wolfgang 1958).4 Early systematical research

\footnotetext{
${ }^{3}$ According to a survey provided by Shaffer (2004), results in the literature indicate that offenders are 1.5 to 7 times more likely than non-offenders to be victims, and victims are 2 to 7 times more likely than non-victims to be offenders.

${ }^{4}$ See Jennings et al. (2012) and Schreck et al. (2008) for surveys on theories considering the victimoffender overlap.
} 
(Hindelang 1976, Hindelang et al. 1978, Gottfredson 1984) focuses on the sociodemographic similarities of victims and offenders (male, young, black, urban, same neighborhoods and habits) and suggests theoretical explanations given by routine activity/lifestyles theories (Hindelang et al. 1978, Cohen and Felson 1979): Daily risky activity brings attractive and poorly guarded targets for crime into close proximity and interaction with potential offenders. This is particularly relevant for youths in the absence of adult supervision (Osgood et al. 1996). It should be noted, however, that quoted early papers (except the work by von Hentig and Wolfgang) are not explicitly dealing with any victimization-offender overlap but are either focusing on criminal behavior or on victimization. Among the first authors who recognized that the link between delinquency and victimization was among the most underdeveloped areas in criminological research are Jenson and Brownfield (1987), Sampson and Lauritsen (1990), and Lauritsen et al. (1991).

In one of the first examinations of the victim-offender overlap, Singer (1981) has put forward the subculture-of-violence explanation, according to which individuals who attack others risk retaliations from former victims, something often reinforced by subculture norms such as the 'code of the street' of gang behavior (see Anderson 1999, Levitt and Venkatesch 2000). In-debth-interviews with street criminals (Jacobs and Wright, 2010) have shown that retaliation is not necessarily addressed against the perpetrator but that random redirection might lash out at any available victim, leading to a general climate of urban violence. The argument is consistent with the idea of crime as an outcome of informal social control (Black 1983). This sociological theory explains a significant amount of crime with a theory of self-help: Individuals who are victimized often in turn use personal violence, theft or property destruction as a means of conflict management. Black (1983) argues that although it is commonly believed that self-help was largely displaced by law in the Western world during the Middle Ages, it has survived in similar patterns in modern societies such as the United States.

Agnew's (1992) general strain and Akers' (1985) social learning theory, too, emphasize the role of former victimization within (sub-) societies which provide motivation and specific training to commit crimes. Last but not least, a further prominent theory providing a foundation for the correlation of victimization and offending is low-self control (Gottfredson and Hirschi, 1990). The authors argue that crime is developed from sensation-seeking behavior that ignores long-term consequences. Offenders appear to have little control of his or her own desires, 
whereas those with greater self-control are "governed by the restraints imposed by the consequences of acts displeasing to family, friends, and the law" (Gottfredson and Hirschi, 1990, p. xv). Individuals who find themselves in places and situations of low self control might become a victim as likely as to commit a crime.

\section{The rational choice approach to victimization and offending}

Some criminological theories of criminal behavior might be considered observationally equivalent or at least similar to economic theories of crime. Merton's strain theory (Merton 1938), for instance, proposes that crime is an illegal attempt to be economically and socially successful: "Offenders are essentially strivers for the American dream" (Schreck et al. 2008, p. 878) who became frustrated because of their relative weak position within the social structure which interferes with the achievement of their expectations (see also Agnew, 1992). Schreck et al. (2008) argue that according to strain theory victimizing people who are lower in the social status hierarchy would produce little gain. Although Merton as well as other authors of seminal criminological contributions such as Hirschi (1969) does not intend to explain victimization, one can infer that preferred victims would be the more wealthy and high status people. The same prediction would follow from rational choice theory in the tradition of Becker (1968): Given utility-maximizing behavior and potential (expected) risks of being detected and punished, would-be offenders choose attractive targets in order to maximize net awards. Thus, according potential victims of rational offenders are typically the economically and socially successful people, the less guarded, those in the proximity of offenders, and those who are visible and available ('exposed'). Papadopoulos (2011) points out that this description also fits basic elements of routine/lifestyle theory (Hindelang et al. 1978, Cohen and Felson 1979). He puts forwards a two-stage explanation of offending and victimization which borrows from the early economic models by Becker (1968) and Ehrlich (1973). In the same vein, Foreman-Peck and Moore (2010), consider the behavior of rational potential victims of violence who minimize the probability of injury, subject to constraints and the achievement of other objectives. However, a clear weakness of this reasoning - and of classical rational choice theory in general is that it ignores the possibility of being a victim and an offender in the same person.

\section{Explanations based on behavioral economics}

Rational choice models are often criticized because they ignore that cognitive restrictions and emotional factors restrict the long-run 'optimality' of individual decisions. Traditional models lack the explicit consideration of the human cognitive 
decision process. As was first pointed out by Simon (1957; see also Simon, 1982, for an overview of his models), the complexity of situations and limitations of both available information and cognitive capacity would lead to decisions under 'bounded rationality' rather than optimal ones, and humans are rather 'satisficers' seeking satisfactory solutions which make her or him happy enough. Bounded rationality is at the heart of modern behavioral economics. Of crucial importance for 'behavioral' explanations of crime are anger, 'uncertainty' (dealing with small probabilities and loss-aversion), hyperbolic discounting (discounting future events), time pressure and shame/guilt (norms); see Garoupa (2003), Van Winden and Ash (2012), McAdams and Ulen (2009), and Entorf (2014) for recent surveys of these findings.

As regards the overlap of victimization and offending, anger seems to be the key motivation of retaliatory behavior, as stressed by many criminological and psychological research papers (see, e.g., Agnew 1992, Kubrin and Weitzer 2003, Jacobs and Wright 2010, Simons and Burt 2011). Anger in response to perpetrated injury, frustration and unfair treatment is a triggering event that motivates 'striking back', not necessarily to the perpetrator himself but also to non-involved bystanders and other available victims, also at some later point in time (see also Haidt 2003, Van Winden and Ash 2012). Such behavior is often the consequence and origin of norms of honor and respect (or fear of dishonor and shame, respectively), prevailing and potentially escalating in sub-cultural societies (Anderson 1999; Kubrin and Weitzer 2003). However, punishing 'unkind' behavior of others or 'negative reciprocity' is not limited to deprived sub-groups but seems to be a social norm rooted in general human behavior, as suggested by findings in Fehr and Gächter (2002). Participants in their experiments revealed some 'altruistic punishment' behavior, i.e. they punished defectors even when they had costly disadvantages from the retaliation. This so-called pro-social behavior has its origin in the notion of fairness as can be seen from the outcome of many ultimatum-game experiments: Responders often destroy any portion of their (guaranteed) gains when they perceive the proposal of the proposer as unfairly low. As known from experiments with public-good games (Fehr and Gächter, 2002), punishment of defectors can be even more effective than reward of cooperators. Laboratory experiments have also shown that the adverse effect of social interaction is not limited to violence: Falk and Fischbacher (2002) report that on average individuals steal the more, the more others steal. 


\section{Irrational or rational retaliation?}

Rational choice theory is questioned by 'irrational' retaliatory behavior of victims and criminals. However, 'altruistic punishment' and 'pro-social behavior' can also be seen as a rational deterrence strategy, as will be explained below. As already stated by the early work of Black (1983), in absence of law or trust in criminal law institutions such as police or courts, victims might be tempted to take the law in their own hands. In particular in disadvantaged neighborhoods and sub-cultural societies where the retaliatory ethic of the 'code of the street' (Anderson 1999) is used in lieu of criminal codes, the credible threat of punishing by strong retaliation might deter potential future perpetrators. 'Rational' retaliation would imply that the deterrent signal to the sub-society can be (random) redirection to the detriment of any available victim (Jacobs and Wright 2010). For would-be victims the potential threat of future retaliation by any other member of sub-cultural groups might be an incentive to join the group and prevents crimes that would have otherwise taken place. Indeed, Sobel and Osaba (2009) argue that youth gangs form in response to government's failure to protect youths against violence. Their empirical results based on gang membership data suggest that the effect of gangs is to reduce the level of urban violence (contradicting Peterson et al. 2004). Although this result seems to be of limited external validity, in particular when gangs participate in drug wars and become part of the crime problem, it confirms Jacobs and Wright (2010), who point at the increased specific deterrence effect when retaliation is addressed within a close micro-structural or relational space: Violators may be deterred even though they have suffered no direct punishment. Thus, we may conclude that the individual motivation of angry reciprocity might be some impulsive and 'irrational' reaction ("irrational" in the sense of traditional rational-choice models) to unfair treatment, but its social effect can be deterrence (see also Van Winden and Ash, 2012, on this point), at least in pre-legal or subcultural spaces.

Scientific contributions rooted in psychology even go one step further. Although individual behavior based on cognitive and emotional factors significantly diverge from what drives decisions of the traditional homo oeconomicus, according to their view human behavior could even be characterized as "ecologically rational" (Frank 1988, Gigerenzer 2005), as human decision making is evolutionary adapted and designed to survive natural selection and to solve fitness-related problems (Van Winden and Ash 2012). 


\section{Empirical Studies on the Victim-Offender Overlap}

As described in the previous paragraphs, theory suggests that the best way to study interactions of offenders and victims would be to observe actions, reactions and counter-reactions of the same people over time. Moreover, in order to estimate relevance and likelihood as well as important covariates and general protectors from victim-offender experiences in the overall population and in everyday life, the analysis should not be limited to microstructural milieus but also cover daily routine activity of average citizens. Unfortunately, the combination of both worlds is almost inaccessible in empirical practice, even if we try to watch people in (unrealistic) laboratory situations. As indicated by the survey by Jennings et al. (2012, Table 1), most samples are restricted to adolescents, school-based samples of children, high school or college students, parolees, psychiatric patients or known offenders and their victims. Only the studies by Klevens et al. (2002), Sparks et al. (1997), Van Dijk and Steinmetz (1983) and Wittebrood and Nieuwbeerta (1999) are based on more general samples, with Wittebrood and Nieuwbeerta (1999) being the only study in the Jennings et al (2012) survey which explicitly addresses the victimoffender overlap and which is based on European data. By contrast, many empirical studies are based on narrative in-depth interviews with criminals (see, in particular, Jacques and Wright, 2008, or Jacobs and Wright, 2010). While such interviews have the advantage that experienced interviewers can go further into relevant questions asked to relevant players, the disadvantage of these papers is that the rather small number of observations limits their external validity and statistical inference. ${ }^{5}$

The alternative is to use relatively large samples from relevant subpopulations; see, e.g., Wittebrood and Nieuwbeerta (1999) and Deadman and McDonald (2004). The data analysed by Wittebrood and Nieuwbeerta (1999) are from a Dutch national crime survey, conducted on roughly 1,900 respondents who were a random sample of the Dutch population above the age of 15. Similarly, Deadman and MacDonald (2004) use data of the 1998 Youth Lifestyles Survey of about 4,000 people aged 1230. As such more general data sets lack the identification of disastrous individual conflicts between offenders and their victims, the milieu of victims and offenders has been approximated by some rich information on age, education, parents, alcohol and drug abuse, peers, health conditions, labour market status etc. So there is no silver bullet for empirical studies analyzing the interaction of criminals and victims. Both ways, narrative interviews and the use of standardized suvey data, have their

\footnotetext{
${ }^{5}$ Jacobs and Wright (2010), for instance, interviewed 52 active street criminals.
} 
merits and problems such that they should be considered as complements rather than substitutes.

Empirical evidence of most published studies on the victim-offender overlap focus on how offending is influencing victimization. This can be seen from the example of one of the most quoted articles in the literature on the victim-offending overlap, Lauritsen et al. (1991). Main conclusions of this seminal study are based on a subsample of the U.S. National Youth Survey regarding adolescents between the ages of 11 and 17, and least squares regressions with victimization as dependent variable, and current and lagged delinquent life styles as regressors (controlling for lagged victimization and socioeconomic factors). The authors mention (but do not report) FIML estimation results which have found that not only did delinquent lifestyle significantly influence victimization, but increases in victimization were significantly linked to increased involvement in delinquent lifestyles. Similar to Lauritsen et al. (1991), Wittebrood and Nieuwbeerta (1999) confirm that a substantial part of the correlation between offending and victimization can be explained by routine activity patterns and general lifestyles. Using logit-type multilevel regression analysis, they further find that offending increases the risk of violent victimization, even after controlling for lifestyle and personal characteristics.

A second strand of empirical literature following Singer (1981), Akers (1985) and Agnew (1992) employ the explanatory power of former victimization on offending. In a survey of existing results on 'victimization causes subsequent offending' Ousey et al. (2011) report mixed results regarding this direction of influence. Hay and Evans (2006), Cullen et al. (2008) and studies characterized as intergenerational transmission of violence ${ }^{\prime 6}$ find that former victimization is positively related to future offending, whereas other authors conclude that victimization decreases subsequent criminal behavior. Ousey et al. (2008) and Jacques and Wright (2008), for instance, propose a 'victimization-termination' rationale according to which victimization represents a seminal traumatic turning point which causes individual to reassess their involvement in risky activities (frequenting bars, alcohol and drug abuse et.) and ultimately curtail committing property and violent crimes. Some contributions from the field of psychology focus on school bullying (perpetration and

\footnotetext{
${ }^{6}$ The psychometric literature on the 'intergenerational transmission' is subsumed under 'cycle of violence' (Widom 1989a, 1989b) and goes rather undetected by the criminological literature (as, for instance, in the survey by Schreck et al. 2008). Recent contributions to this strand of literature are, e.g., Kim (2008), Maas et al. 2008, and Yun et al. 2011), and, in the field of economics, Currie and Tekin (2012). They show that childhood maltreatment is strongly related to future offending.
} 
victimization) and their consequences later in life. Based on evidence from a meta analysis, Farrington et al. (2012) conclude that the link between being bullied and future offending is rather weak, whereas the authors find highly significant links between school bullying and later offending. Unfortunately, this study has neglected the potentially important impact of bullying on later victimization.

Given the high overlap of offending and victimization, it seems promising to complement the analyses of potential links between offending and victimization by econometric studies on simultaneous or at least reciprocal relationships. It is only recently that research widens its perspective to study both the influence of victimization on offending and the reverse causation. In their review of the 'reciprocal' literature, Ousey et al. (2011) mainly refer to two studies, Schreck et al. (2006) and Wilcox et al. (2006), who both use repeated panel waves to study the dynamics of the victimization-offending-victimization feedback. Both studies confirm what Ousey et al. (2011) call the 'reciprocal escalation hypothesis', i.e. victimization increases offending, which in turn provokes higher victimization. By contrast, results by Ousey et al. (2011) themselves based on dynamic panel data from four follow-up surveys among 12 to 15-year-old students are in line with the conclusion that offending is reduced by one's own previous victimization.

Silver et al. (2011), Foreman-Peck and Moore (2010) and Shaffer (2004), independently of each other, follow a different approach considering victimization and offending as a joint process, i.e. both variables are treated as dependent variables which are determined by exogenous factors. A crucial element of the so-called seeming-unrelated-regressions model (SUR), or, if dependent variables are dichotomous, bivariate Probit model used in quoted papers, is the consideration of correlated residuals, i.e. latent factors that cover unobserved heterogeneity influencing the joint victimization-offending system. Silver et al. (2011) consider violent offending and victimization within a sample of psychiatric patients. The authors confirm previous results that most significant factors of victimization would also hold for offending. Their important finding is that both offending and victimization are affected by some positively correlated unobserved factors not accounted for in the data. The authors presume that violence and victimization may be linked through interactional processes such as provocation and retaliation, or chronic relationship conflicts. The same positive interrelationship between unobserved drivers of victimization and offending has been documented by Shaffer (2004) and Foreman-Peck and Moore (2010). Their empirical models only differ 
with respect to included explanatory variables: Shaffer (2004) has a strong focus on the significant role of peer effects, whereas Foreman-Peck and Moore (2010) highlight the importance of risk aversion (low-risk aversion increases the likelihood of becoming a victim) and time-preference (more impatient people are more likely to be violent). They use a sample of pedestrians who were approached in the Cardiff city center in the evening and asked if they would participate in a survey on attitudes to disorder. The strong positive effect of a joint latent factor found in all three articles is highly significant after controlling for numerous socioeconomic, parental, life-style/routine activity, peer-group, and clinical variables, as well as time preferences and risk aversion. The robustness of these results suggests that despite the long list of well-known factors, both victimization and offending are still subject to positively associated latent factors, of which the tendency of negative reciprocity and pro-social behavior are probably very important ones.

Also the paper by Deadman and MacDonald (2004) is based on bivariate Probit modeling. Their approach is innovative in that they apply a recursive bivariate Probit system to study the victim-offender overlap. Using data of the 1998 Youth Lifestyles Survey (YLS), they consider victimization in the equation of interest and treat offending as one of its explanatory factors. Offending is explained in a second equation using variables which the authors consider truly exogenous to the system of victimization and offending (such as expulsion from school and truancy, excessive drinking and drug use), i.e. these variables are significantly associated with the offending variable but not the victimization variables. Deadman and MacDonald (2004) find that former offending is a significant factor of victimization. As their research is restricted to the analysis of criminal behavior as a cause of victimization, the open question remains whether neglecting the reverse causal ordering is justified. In the next chapter, we try to answer this question using German data.

\section{Data and Descriptive Statistics}

\section{Background information}

The econometric analysis is based on a survey of 1.193 residents drawn from the German population (henceforth referred to as German Crime Survey). The sample used in this paper consists of 960 adults above the age of 18. The data has been collected in 2004 using a questionnaire on socioeconomic and parental backgrounds, criminal experience (offending and victimization), education, professional experience, peers and social capital, as well as assessments regarding deterrence. The 
sample has originally been designed as a nationwide control group (of nonimprisoned citizens) to the German Inmate Survey (GIS, see Entorf et al., 2008, and Entorf, 2009, for details). ${ }^{7}$ The sample design is based on the inmate survey. The stratification is by education, age, gender, and nationality/migration background such that the sample distribution of these variables should resemble the one of the inmate survey. ${ }^{8}$ Thus, compared to the overall German population, the education level is rather low, most people are relatively young and males are strongly overrepresented. With respect to these characteristics, the composition of the control group reveals high coincidence with the one of the inmate survey. The only exception is the distribution of foreign citizens. The realized share of non-German citizens in the sample $(12 \%)$ is somewhat higher than in the German resident population $(9 \%)$, but the share is significantly below the level in the inmate survey (19\%).

\section{Explanatory factors of victimization and offending}

Similar to, e.g., Wittebrood and Nieuwbeerta (1999) and Deadman and MacDonald (2004), this study follows the strategy of using a relatively large sample without obvious attachemement to subcultural milieus. This brings about the advantage of being able to evaluate the size of relative frequencies of occuring victim-offender relationships in everyday life, at least for citizens represented by the sample (i.e., for the main part, males and people with low education). At the same time, the disadvantage is the unclear identification of individual conflicts between offenders and their victims. ${ }^{9}$ Thus, their milieu has to be approximated by rich information on age, education, parents, alcohol and drug abuse, peers, health conditions, labour market status etc.

Table 1 provides descriptive statistics. The subsequent econometric analysis is based on adults (18 years and above) who already left school. Reported criminogenic factors are subsumed under different categories. As emphasised before, not all variables can be assigned to theories in an unambiguous one-to-one relation, but may be subject to observational equivalence. According to the economic focus of the

\footnotetext{
${ }^{7}$ Further research papers based on these data sets are Entorf and Sieger (2010), Entorf (2012), Pichler and Römer (2011, 2013), Loureiro and Alvarez (2012). The GIS itself further includes questions regarding prison conditions, rehabilitation programs and recidivism. It comprises data on 1,771 inmates in 31 German prisons.

${ }^{8}$ The population survey has been performed by tns-Infratest.

${ }^{9}$ A remarkable example of gathering information on potential individual conflicts is Card and Dahl (2011), who studied the impact of unexpected emotional cues on violent behavior in conflict-prone families. Their identification is based on unexpected losses of home teams in American football.
} 
study, indicators of realized and potential economic success and wealth, here summarized as economic status and well-being, are taken as point of departure. As expected from previous research on testing causal effects of education on crime (Lochner and Moretti 2004, Machin et al. 2011; see also Entorf and Sieger 2010 using the data of this study), absence of school degrees ('no school') and finishing only some basic school ('Hauptschule', ISCED 2) should have increased the probability of a criminal career, whereas higher degrees 'Realschule/FOS' and top degrees 'Abitur/University' (ISCED 4 or higher) are expected to reduce criminal risk. Subsequent empirical results are based on low/no school degree which summarizes the categories 'no school' and 'Hauptschule' and some respondents who attended special-needs schools. According to classical rational choice arguments, unemployed persons should be less attractive targets of crime but might have higher incentives for (property) crime. Good health is a dummy variable which is set equal to 1 when respondents chose "no serious disease" as response instead of one of several health problems mentioned in the questionnaire. Good health is expected to be associated with good physical fitness and high self esteem such that it should reduce the probability of victimization (see Finkelhor and Asdigian 1996, Hassouneh-Phillips and McNeff 2005), in particular when compared to disabled or mentally ill people. The problem of excessive debt obligations ("have problems paying pack duties") is an economic factor of crime, because it brings about incentives for property crimes. It is somewhat surprising that this covariate of crime has gone rather undetected so far (with the exception of McIntyre and Lacombe 2012). As such debt problems might also be the outcome of a hedonistic lifestyle, it could likewise be assigned to the category low self control. Serious illicit drug or alcohol problems is perhaps an even more important factor of low-self control which is often associated with victimization but also with criminal behaviour. ${ }^{10}$

Further standard covariates of crime are age, gender, marital status, urbanity, and migration background. In criminological studies of the victim-offender overlap these variables are summarized as factors of routine activity/lifestyle (criminological studies would also add education and economic status variables to this category). Inspired by Hirschi and Stark (1969), according to many articles found in the literature religious affiliation has a crime reducing effect (see Baier and Wright,

\footnotetext{
${ }^{10}$ Illicit drug use and heavy drinking is a severe problem in prisons. According to the GIS inmate survey, the problem affects about one third of the German prison population. By contrast, the survey of the non-imprisoned resident population revealed a rather small share of only $2.2 \%$.
} 
2001, for a survey). In the present study, religion is covered by no confession ${ }^{11}$ and Muslim religion. Among the factors representing peers, family and sub-cultural influence, a very strong effect is expected from criminal family background (parents or siblings with criminal record, i.e. previous conviction in a court). Friends and peers, too, should be of relevance for both offending and victimization. For example, a large number of loose friendships could be an indicator of sub-cultural influences, whereas one close friend might have the opposite effect of protecting from 'bad' risky lifestyles.

\section{Descriptive evidence on the victimization-offender overlap}

Tables 2 and 3 give a first impression of the relevance of the offender-victimization overlap based on the population survey presented in Table 1. The survey questionnaire covers previous offending as presence of any previous conviction (yes/no) and by type of crime (violent, property, road traffic, other). In total, 9.7\% of the respondents report a conviction, of which we treat survey participants with road traffic offenses (speeding, dangerous driving, etc) as non-offenders. This applies to $2.6 \%$ of the sample. In order to identify relevant differences between the resident population and prison inmates, descriptive evidence of Table 2 also uses data of the inmate survey, GIS. From the latter, only inmates under criminal law are considered, i.e. individuals under juvenile custody and inmates of pretrial custody are excluded. Moreover, we only consider adults of at least 18 years of age.

Evidence on victimization is based on the following survey question [part in brackets only applies to the inmate survey questionnaire]: "Did you yourself once or more often become the victim of an offence [before the present term in custody]". Respondents were asked to tick one of the following three possibilities: No/ Yes, relatively petty (victim of common theft or similar)/ Yes, quite massively, as the victim of the following offence(s):_-".

Descriptive results are in line with previous research. A substantial share of both inmate and population sample experienced previous victimization (Table 2). The smallest share of victimization is reported for non-offenders without previous conviction. It amounts to 25.9 percent, of which the large majority of 23.1 percent was perceived as "relatively petty", i.e. a theft or similar property crime. Convicted

\footnotetext{
${ }^{11}$ This implies that individuals do not consider themselves as members of any organized religious community, first and foremost not as member of the catholic or protestant churches.
} 
offenders report much higher rates of victimization, namely 52.9\% (German Crime Survey) and $43.1 \%$ (German Inmate Survey), respectively. The gap between nonimprisoned non-offenders, non-imprisoned ex-offenders and imprisoned offenders becomes very pronounced when massive victimization is compared. This share is only 2.8 percent among the non-offenders in the "normal" population covered by the German Crime Survey, but 10.3 percent for the German Crime Survey with a criminal record, and even 18.8 percent for prison inmates.

The reverse situation, i.e. offending by previous victims, is described in Table 3. Here reciprocal behaviour can be confirmed as relevant covariate of crime: While nonvictimized survey participants have a crime rate of 4.6 percent, it is 13.5 percent for previous victims. If participants report massive victimization, then about one out of five $(21.9 \%)$ has a criminal record. The majority $(9.4 \%)$ of them have been convicted for property crime, $6.3 \%$ have a record for violent crime.

\section{Econometric Evidence}

The econometric analysis is based on four sequential steps. To evaluate main factors and to analyse similarities and differences among the determinants of offending and victimization, the first step is to treat both variables of interest within two separate and independent Probit equations. The second step will then be using a more efficient seemingly unrelated bivarate Probit estimation that takes the potential correlation between the residuals of both equations into account. Thirdly, a recursive bivariate model will treat victimization as dependent and offending as explanatory variable. The fourth step will go beyond this framework known from previous reseach (Deadman and MacDonald 2004) and test the reverse causal ordering, i.e. the role of victimization on criminal behavior. Several sensitivity analyses validate the robustness of results, in particular with respect to the exclusion restriction and the role of family factors on offending.

\section{Univariate Probit analysis}

As both offending and victimization are measured as binary variables, the first statistical approach is using (univariate) Probit models. They analyse the probabilty $P$ of the occurence of an event $Y$ (i.e. offending or victimization take the value $\mathrm{Y}=1$ ) by using a normally distributed link function $\Phi$, i.e. $P\left(Y_{i}=1\right)=\Phi\left(X_{i} \beta\right)$, where $Y_{i}$ represents the outcome variable of 'victimization' and 'offending', respectively, of 
individual $i, X_{i}$ represents a vector of explanatory factors, and $\beta$ is the vector of corresponding weights estimated by maximum likelihood methods (see, e.g, Wooldridge, 2010). Results of the univariate Probit analysis (ignoring problems of endogeneity of offending and victimization as well as joint dependencies) are presented in Table 4a. We report marginal effects, i.e. the change of the endogenous probabilty in response to a one-unit change of the explanatory variable. For explanatory binary $(1 / 0)$ dummy variables, the reported marginal effect is the average change of individual probabilties (in being a victim or an offender) in response to a status change from 0 to 1 (for example from being employed to 'unemployed $=1$ ').

At this stage, results are still preliminary and only briefly discussed. Higher criminal activity is significantly (at least at the $10 \%$ significance level) associated with low or no education, being male, originating from a family with a criminal record of parents or siblings, broken homes (parents divorced or separated) and excessive indebtedness, whereas the likelihood of victimization increases with good or high education, being a member of a large peer group, having a job (instead of being unemployed), existing health problems, being single, divorced or widowed, not being a member of an organized religious confession, having large peer groups, and stemming from a family with previous criminal involvement.

The picture doesn't change much when victimization and offending are added as regressors in the offending and victimization equation respectively, still ignoring any potential endogeneity of these variables (see Table $4 \mathrm{~b}$ ). It turns out that both victimization as well as offending are highly significant covariates in respective equations. Thus, the victim-offender overlap persists even after controlling for a rich list of factors known from theories of the economics of crime, routine activity/ lifestyle, low self control, and subcultural influence. As regards other parameter estimates, the only significant change occurs for 'criminal record of parents or siblings'. Here effects become small or even insignificant after victimization and offending have been controlled for which indicates some strong interaction of family factors with the involvement in criminal activities (as offender or victim).

\section{Seemingly unrelated bivariate Probit analysis}

The second step is to test whether common latent factors underlying both victimization and offending do exist and whether they persist after controlling for observed factors. For this purpose, a (seemingly unrelated) bivariate Probit model is 
estimated (see Silver et al. 2011, Foreman-Peck and Moore 2010, Shaffer 2004, and Deadman and MacDonald 2004 for similar strategies). The empirical specification of the bivariate Probit modeling of offending, $\mathrm{O}$, and victimization, $\mathrm{V}$, is

$$
\begin{aligned}
& O_{i}^{*}=X_{i} \beta_{1}+\varepsilon_{1 i} \\
& V_{i}^{*}=X_{i} \beta_{2}+\varepsilon_{2 i}{ }^{\prime}
\end{aligned}
$$

where the residuals $\varepsilon_{1 i}$ and $\varepsilon_{2 i}$ are jointly distributed as bivariate normal with means 0 and unit variances. $O_{i}^{*}$ and $V_{i}^{*}$ are latent indicators of observed binary realizations of $O_{i}$ and $V_{i}$, respectively. ${ }^{12}$ The difference between univariate and bivariate Probit is the potential nonzero correlation $\rho$ between the unobserved explanatory factors in the two equations.

A first test is to run model (1) without further controls $X_{i}$. Thus, any correlation between $\varepsilon_{1 i}$ and $\varepsilon_{2 i}$ would arise from common unobserved factors and from misspecification due to omitting observables if these were potentially common factors of both endogenous variables. The estimate of the naïve model gives $\rho=0.345$ with a standard error of 0.081 . The likelihood-ratio test of the hypothesis $\rho=0$ corresponds to a highly significant p-value of 0.0000 .

Including a full set of control variables to the bivariate Probit models reveals that the correlation remains high and significant at the $1 \%$ level (Table 5). Thus, the correlation of the residuals is not due to some spurious relationship, but it remains valid after controlling for an array of demographic, economic, demographic, and social variables. Similar findings have been reported by authors quoted above. In Table 5b, insignificant variables have been omitted. In order avoid any potential bias from cumulative effects due to retrospective reporting, the only exceptions are age and age-square which are generally retained (here and henceforth) despite their insignificance (which is reinforced by mutual collinearity). While parameter estimates of remaining variables in Table $5 \mathrm{~b}$ are almost unchanged compared to Table 5a, the significance levels improve somewhat upon the full specification.

\section{Recursive bivariate Probit analysis}

The third step is to run a recursive bivariate Probit approach. "Recursivity" in bivariate Probit models applies to bivariate Probit models with a recursive ordering

${ }^{12} O_{i}=1$ if the propensity to offend, $O_{i}^{*}$, exceeds a certain but latent threshold, $O_{i}=0$ otherwise. The same applies to $V_{i}^{*}$. See econometric or statistical textbooks (e.g. Wooldridge 2010) for details. 
of dependent variables, i.e. in the two-equation case the dependent variable of, say, the second equation can be used as regressor of the first equation, but not vice versa. Simultaneous equations with both continuous and dummy endogenous variables have been introduced by Heckman (1978). Maddala (1983, p. 122) categorizes it among the models of recursive dichotomous choice. Wooldridge (2010, Ch. 15.7.3) covers them as models with a 'binary endogenous explanatory variable' which allows maximum-likelihood estimating of a causal structure despite the endogenous nature of both on victimization and offending. We first hypothesize victimization as dependent variable (as Deadman and MacDonald 2004), i.e. we consider

$$
\begin{aligned}
& V_{i}^{*}=X_{i} \beta_{1}+\delta O_{i}+v_{1 i} \\
& O_{i}^{*}=X_{i} \beta_{2}+Z_{i} \beta_{3}+v_{2 i}
\end{aligned} .
$$

Given $\delta \neq 0$, equation (2) imposes the hypotheses that offending has an influence on victimization. A complementary exogeneity test depends on significance of the coefficient of correlation between residuals, $\rho$. Its insignificance after including offending into the victimization equation would imply that the victimization equation could be treated independent of the second equation and that offending could be treated as exogenous to victimization anyway (see Maddala, 1983, Monfardini and Radice, 2008).

Model (2) is estimated using maximum-likelihood methods. Note that the endogenous nature of $O$ on the right-hand side variable of the victimization equation can be ignored in nonlinear maximum likelihood estimations (see Wooldridge 2010, Ch. 15.7.3, Greene and Hensher 2010, p. 90-91, and Greene 2008, p 823, for details). Besides consistency and efficiency of ML estimation, another advantage of the recursive bivariate Probit model is that (different) exogenous variables may appear in both equations. Maddala (1983) pointed out that there should to be at least one 'instrument' $z$ in the 'exogenous' equation (i.e. it should be excluded and redundant in the equation for the endogenous variable of interest). However, Wilde (2000) has shown that such exclusion restriction is not generally needed in multi-equation Probit systems and that identification is achieved as soon as both equations of bivariate Probit models contain a varying exogenous regressor (see also Monfardini and Radice, 2008, and Wooldridge, 2010, chapter 15.7.3).

In Table 6, both ways are followed. In Table 6a, after discarding totally insignificant variables, a full model has been estimated, whereas in Table $6 \mathrm{~b}$ excessive 
indebtedness is excluded from the victimization equation but highly significant in the offending equation. The difference in the log-likelihoods is very small and the exclusion can be easily confirmed on grounds of a likelihood-ratio test ( $\mathrm{p}$ value $=0.34$ ). As above (Table 5), offending turns out being a highly significant factor of victimization. The only remarkable difference compared to seemingly unrelated Probit presented before is the insignificance of criminal record of parents or siblings in the victimization equation. Also the significance of the correlation between unobserved residuals has been reduced. The p-value is 0.038 for the full model and 0.062 for the restricted model. Subsequent sensitivity analyses (Table 8) confirm a significant $\rho$-estimate after exclusion of redundant variables such that the validity of model (2) can be confirmed.

The interpretation of parameter estimates suggests that own criminal careers seem to be a major source of victimization risks. They mask potential family influences and render them of second order importance. Moreover, including offending as factor of victimization affects the latent factor driving both offending and victimization and leads to a negative correlation of residuals. The same finding is reported by Deadman and MacDonald (2004).

So far, the econometric analysis has followed previous publications. However, there is no particular reason why the econometric analysis of the victim-offender overlap should be limited to models where victimization is studied in response to victimization, even when endogeneity of regressors is taken into account (as, for instance, by FIML estimation in Lauritsen et al., 1991, or recursive bivariate Probit modeling in Deadman and MacDonald, 2004). It is likewise important to evaluate size and significance of the marginal effect of victimization on offending. To do so, in the following, we go beyond model (2) by estimating the alternative specification

$$
\begin{aligned}
& O_{i}^{*}=X_{i} \beta_{1}+\delta V_{i}+v_{1 i} \\
& V_{i}^{*}=X_{i} \beta_{2}+Z_{i} \beta_{3}+v_{2 i}
\end{aligned}
$$

Table 7 presents marginal values. As before, a full model (7a) and a restricted model (7b) have been estimated. Good health condition is excluded from the hypothetical 'endogenous' offending equation but retained in the potentially 'exogenous' victimization equation. The restriction does not significantly affect the log-likelihood of the model (the likelihood-ratio test shows a p-value of 0.47 ).

The estimation result invalidates model (3): Firstly, victimization turns out to be insignificant for offending, and secondly, the correlation between residuals is 
insignificant. These findings indicate that the offending equation can be treated independent of the victimization equation and that victimization experiences are not responsible for criminal behavior. As this outcome is congruent to the estimate of model (2), it supports the often preferred 'offending causes victimization' view observed in the literature (see Ousey et al. 2011) and justifies the limitation on model (2) by Deadman and MacDonald (2004).

\section{Sensitivity analysis}

Some sensitivity analysis has been performed in order to check robustness of results. In particular, the channel of influence of the criminal parental background is worth to be considered in more detail. However, we first reconsider previous estimates in the light of alternative specifications and exclusion restrictions. Table 8 a reexamines estimation of model (2) by excluding more than just one variable from the victimization variable. In addition to the exclusion of excessive indebtedness in Table 6b, now male gender, no confession, criminal record of parents or siblings as well as parents divorced or separated have been excluded from the victimization equation and serve as 'instruments' in the offending equations. The restriction does not significantly change the log-likelihood ( $p$-value of likelihood-ratio test with 5 degrees of freedom $=0.636$ ), and also parameter estimates are almost the same as in Table 6 . The same holds for results presented in Table $8 \mathrm{~b}$, where in addition also insignificant factors of offending are discarded ( $p$-value of likelihood-ratio of Table $8 \mathrm{~b}$ against specification in Table 8a: 0.568). Inspecting this final parsimonious specification, the correlation of residuals is highly significant at the $1 \%$ level.

Repeating the exercise for the estimation of model (3) gives the same picture (see Table 9). Results in Table 7 do not differ significantly from those in Table 9a (where a larger number of exclusions were considered). Also omitting insignificant variables from the presumed 'exogenous' equation in this specification, i.e. from the one for victimization, does not have strong effects (see Table 9b). The largest change of parameter estimates occurs for the one on criminal record of parents or siblings which is 0.16 in the parsimonious specification, whereas it was 0.14 before. The correlation coefficient $\rho$ keeps insignificant. Likelihood-ratio tests confirm that imposed restrictions do not significantly reduce the log-likelihood (Table 9a vs. Table 7a: -value $=0.660$, Table 9b vs. Table 9a: $p$-value $=0.278$ )

So we may conclude that results are robust against exclusion of insignificant variables. There still seems to be some inconsistency between the strong significance 
of criminal family background ("criminal record of parents or siblings") in the univariate Probit model of offending behavior (Table 4a) as well as in the seemingly unrelated Probit equation of offending (Table 5), whereas it becomes insignificant in recursive estimates of offending (see estimates of model (3) in Tables 7 and 9b). Evidently, here the high collinearity between familial criminal problems and the linear combination of other regressors, including victimization, has caused high standard errors. So in order to decide whether criminal record of parents or siblings should be omitted from the final specification or not, results in Table 9 are replicated without this factor (see Table 10). Likelihood-ratio tests reveal that the model including the criminal family background should be preferred (Table 10a vs. Table 9a: -value $=0.051$, Table $10 \mathrm{~b}$ vs. Table 9b: -value $=0.065)$. Thus, the high coefficient on victimization in Table 10 most likely results from an omitted variable bias such that we can confirm the validity of results presented in Table 9.

\section{Discussion of results}

Summarizing results, we can conclude that there is a recursive system of victimization and offending equations, with victimization depending on offending but not vice versa. The finding confirms and justifies previous modeling of the victim-offender overlap by Deadman and MacDonald (2004). In line with their research and later work (e.g., Foreman-Peck and Moore 2010, Silver et al. 2010) we find common unobserved heterogeneity which lead to correlated residuals of the equation system of offending behavior and victimization experiences.

The subsequent discussion of factors of victimization and offending is mainly based on Table $8 \mathrm{~b}$, because it captures the most parsimonious specification of model (2) and because parameter estimates have been pretty stable across alternative variations of the model. First and foremost, offending turns out as one of the most important covariates of victimization. Conditional on previous offending, the probability of having experienced victimization is high: The average victimization probabilities of offenders and non-offenders differ by 0.63 . Elaborating further on the drivers of victimization, jobholders with more schooling seem to face higher risks of being target than unemployed people or those with a low or no school degree. Glaeser and Sacerdote (1999) report the same result using the US National Crime Victimization Survey. Analyzing victimization surveys of six Latin America cities, also Fajnzylber et al (2000) find that being unemployed is associated with higher victimization rates. The result is in line with the argument that optimizing criminals "victimize the wealthy before the poor" (Glaeser and Sacerdote 1999) which is also 
confirmed by Vollaard and Van Ours (2011); they find that owners of expensive own-occupied homes face a relatively high risk of burglary. A further explanation is that employed individuals are more exposed to risk because they spend more time in public areas during their commute to and from the workplace than do unemployed people. Sampson (1985) reports that even after controlling for other neighbourhood characteristics victimisation rates of residents of high mobility areas are at least double those of residents in low mobility neighbourhoods. Notwithstanding these findings, the result is still somewhat surprising because the wealthy and well educated are also expected to undertake more self-protection than the poor and the less educated. Hence an alternative explanation could be that higher levels of education may be associated with less underreporting of crimes.

Other factors show expected effects. Physical fitness and marriage are significantly linked to lower victimization rates, confirming results by, e.g., Finkelhor and Asdigian (1996, for health) and Glaeser and Sacerdote (1999, for marriage). Married people seem to avoid risky lifestyle such that their probability of being victimized is reduced by about 12 percent compared to single, divorced or widowed individuals. Large peer groups increase the risk exposure. More than 20 (loose) friendships increase the risk of victimization by more than 7 percent which confirms predictions of routine activity/lifestyle theory. Previous Probit estimates based on victimizations studies found being a male among the risk factors (Glaeser and Sacerdote 1999, Fajnzylber et al. 2000). In our study 'male' has the expected sign but found insignificant in the preferred recursive specification (and only weakly significant elsewhere). Insignificance for victimization also holds for the criminal family background and separated or divorced parents. This may be surprising at first glance, but it should be noted that these factors still have an indirect impact on victimization. The channel of influence of these variables follows the recursive structure of the model, i.e., they first impact offending, and then, via offending, also victimization depends on parental responsibility and family problems. So the lacking significance in the structural model equation of victimization is not necessarily at odds with expectations.

This leads to the discussion of covariates of offending, i.e. the "exogenous" equation of the two-equation system, where criminal background of parents or siblings and parents divorced or separated indeed belong to the most important covariates of offending. This finding confirms results found elsewhere in the literature (see, e.g., Rowe and Farrington 1997, Amato 2000, and Hjalmarsson and Lindquist 2012). As 
expected from previous research on testing causal effects of education on crime quoted above, also absence of school degrees or finishing only some basic school ("low/no school degree") increase the probability of a criminal career. Also as usual, men are more likely associated with criminal involvement. In accordance with other publications (see Baier and Wright, 2001), religious affiliation seems to have a crime reducing effect. Individuals who ticked no confession in their questionnaire have a four percent higher propensity of being convicted for an offense. However, Heaton (2006) argues that the negative effect of religion on crime might suffer from an endogeneity bias. As this issue is beyond the scope of this paper, we do not investigate this question further and can only leave it for further research. Finally, we observe a strong association of crime with excessive personal debt obligations which confirms recent results by McIntyre and Lacombe (2012), who use spatial data and find that personal indebtedness is related to personal theft crimes.

Interestingly enough, some variables show no significant effects. Similar to Bell et al. (2013) we do not find any effect of migration background on victimization. There is also no such effect on offending which is confirming Bianchi et al. (2012) and in line with the recent survey by Bell and Machin (2013). Likewise, serious drinking or illicit drug problems remain insignificant. This finding is contrary to results by Jensen and Brownfield (1986) and Lauritsen et al. (1991). The reason for its insignificance can be seen in the small number of applicable cases and its redundancy caused by control variables such as parental influence, peer pressure and excessive indebtedness.

\section{Summary and Conclusions}

Theoretical and econometric investigations of the empirically well documented individual victim-offender overlap are rare. The contribution of this paper is threefold. Firstly, it discusses theoretical considerations, which so far are dominated by contributions from criminology. Secondly, a review of empirical results is given, with a focus on the joint modeling of victimization and offending and the discussion of the direction of influence. The third part consists of an econometric study based on German retrospective survey data on individual offending and victimization experiences.

From the classical economics point of view, rational offenders choose lucrative targets and wealthy victims before less attractive victims. The paper contrasts this view with 'behavioral' explanations of victim-offender situations, of which anger 
seems to be of crucial importance. The paper also discusses 'irrational' and 'rational' impulsive retaliatory behavior.

Searching through the empirical papers on the victim-offender overlap, it turns out that the topic is an under-researched area in economics. Only few authors (Deadman and MacDonald 2004, Foreman-Peck and Moore 2010) belong to economic departments, whereas the bulk of contributions focus on criminological explanations and make use of samples from deviant minorities. Regarding the joint dependence of victimization and offending on common factors such as risky lifestyle and routine activity, we observe similar patterns across many papers. However, no consensus has been found on the causal relation between victimization and criminal involvement.

The own study employs recursive bivariate Probit modeling to allow endogeneity of offending and victimization, and to analyze simultaneous factors of offending and victimization. After testing alternative hypotheses of recursive ordering and performing several robustness checks, the results of the study confirm and justify previous bivariate Probit modeling (Deadman and MacDonald 2004), according to which victimization has been chosen as dependent variable of the bivariate system (whereas victimization turns out as insignificant for offending). Among the covariates of crime, low education, broken homes and criminal family problems are important risk factors, but also personal indebtedness problems play a significant role. Besides criminal involvement, very large peer groups increase the risk of victimization, whereas married and healthy people have a significantly lower risk of becoming a crime victim. In line with some rational choice behavior of offenders, presented econometric results confirm that victimization is associated with being employed and education which, however, could also be explained by higher mobility and commuting of jobholders in high density areas.

The advantage of the used data set is that it is not limited to adolescents or deprived subgroups of the population but provides a sample of average citizens. A major problem of research on the victim-offender overlap is the lack of panel data which would allow following individuals over time in order to measure criminal activities after the event of victimization, and victimization in response to offending. Moreover, unobserved heterogeneity is an important issue when studying crime. A limitation of cross sectional data is that they have to rely on retrospective information. It is hoped that the study will encourage more research with better data on the fascinating and still widely neglected subject of the victim-offender overlap. 


\section{References}

Agnew, R. (1992) Foundation for a General Strain Theory. Criminology 30(1), 47-87.

Akers, R.L. (1985) Deviant Behavior: A Social Learning Approach. Belmont, CA: Wadsworth.

Amato, P.R. (2000) The consequences of divorce for adults and children. Journal of Marriage and the Family, 62, 1269-1287.

Anderson, E. (1999) Code of the Street, New York: Norton.

Baier, C.J. and B.R.E Wright (2001) If you love me, keep my commandments: A MetaAnalysis of the Effect of Religion on Crime. Journal of Research in Crime and Delinquency, 38(1), 3-21.

Becker, G.S. (1968) Crime and punishment: An economic approach. Journal of Political Economy, 76(2), 169-217.

Bell, B., F. Fasani and S. Machin (2013) Crime and immigration: evidence from large immigrant waves. Review of Economics and Statistics, forthcoming.

Bell, B. and S. Machin (2013) Immigration and crime. In: International Handbook on the Economics of Migration (eds. A.F. Constant and K.F. Zimmermann), pp. 353-372, Cheltenham: Edward Elgar.

Bianchi, M., P, Buonanno and P. Pinotti (2012) Do immigrants cause crime? Journal of the European Economic Association, 10(6), 1318-47.

Black, D. 1983 Crime as social control. American Sociological Review, 48, 34-45.

Card, D. and G.B. Dahl (2011) Family violence and football: The effect of unexpected emotional cues on violent behavior. Quarterly Journal of Economics, 126, 1-41.

Cohen, L.E. and M. Felson (1979) Social change and crime rate trends: A routine activities approach. American Sociological Review, 44, 588-608.

Cullen, F.T., J.D. Unnever, J.L. Hartman, M.G. Turner and R. Agnew (2008) Gender, bullying victimization, and juvenile delinquency: a test of general strain theory. Victims and Offenders, 3(4), 346-364.

Currie, J. and E. Tekin (2012) Understanding the cycle: Childhood maltreatment and future crime. Journal of Human Resources, 47(2), 505-549.

Deadman, D., and Z. MacDonald (2004) Offenders as victims of crime? An investigation into the relationship between criminal behaviour and victimization. Journal of the Royal Statistical Society Series A, 167(1), 53-67.

Ehrlich, I. (1973) Participation in illegitimate activities: A theoretical and empirical investigation. Journal of Political Economy, 81(3), 521-565.

Entorf, H. (2009) Crime and the labour market: Evidence from a survey of inmates. Journal of Economics and Statistics 229, 254-269.

Entorf, H. (2012) Expected recidivism among young offenders: Comparison of specific deterrence under juvenile and adult Criminal Law. European Journal of Political Economy, 28(4), 414-429.

Entorf, H. (2014) Certainty and Severity of Sanctions in Classical and Behavioral Models of Deterrence: A Survey. In: Encyclopedia of Crime and Criminal Justice, (eds: G. Bruinsma, and D. Weisburd), Heidelberg: Springer, forthcoming.

Entorf, H., Meyer, S., Moebert, J. (2008) Evaluation des Justizvollzugs. Ergebnisse einer bundesweiten Feldstudie. Heidelberg: Springer.

Entorf, H. and P. Sieger (2010) Unzureichende Bildung: Folgekosten durch Kriminalität. Report on behalf of Bertelsmann-Stiftung, Gütersloh. 
Fajnzylber, P., D. Lederman, and N. Loayza (2000) Crime and Victimization: An Economic Perspective. Economía, 1(1), 219-302.

Farrington, D.P., F. Lösel, M. Ttofi, and N. Theodorakis (2012) School bullying, depression and offending behaviour later in life: An updated systematic review of longitudinal studies. Stockholm: Swedish National Council for Crime Prevention.

Falk, A. and U. Fischbacher (2002) Social norms. "Crime" in the lab - detecting social interactions. European Economic Review, 46, 859-869.

Fehr, E. and S. Gächter (2000) Fairness and retaliation: The economics of reciprocity. Journal of Economic Perspectives, 14(3), 159-181.

Fehr, E. and S. Gächter (2002) Altruistic punishment in humans. Nature, 45, 137-140.

Finkelhor, D. and N.L. Asdigian (1996) Risk factors for youth victimization: Beyond a lifestyles theoretical approach. Violence and Victims, 11(1), 3-20.

Foreman-Peck, J. and S.C. Moore (2010) Gratuitous violence and the rational offender model. International Review of Law and Economics, 30(2), 160-172.

Frank, R.H. (1988) Passions within Reason. New York: Norton.

Garoupa, N. (2003) Behavioral Economic Analysis of Crime: A Critical Review. European Journal of Law and Economics, 15(1), 5-15.

Glaeser, E. and B. Sacerdote (1999) Why is there more crime in cities? Journal of Political Economy, 107(6, part 2), S225-S258.

Gigerenzer, G. (2005) Is the mind irrational or ecologically rational? In: The Law and Economics of Irrational Behavior (eds F. Parisi and V.L. Smith), Stanford: Stanford University Press.

Gottfredson, M.R. (1984) Victims of Crime: The Dimensions of Risk. Home Office Research Study No. 81, London: Her Majesty's Stationery Office.

Gottfredson, M.R. and T. Hirschi (1990) A General Theory of Crime. Stanford: Stanford University Press.

Greene, W., and D.A. Hensher (2010) Modeling Ordered Choices. A Primer. Cambridge: Cambridge University Press.

Haidt, J. (2003) The moral emotions, in: Handbook of Affective Sciences (eds. R.J. Davidson, K.R. Scherer and H.H. Goldsmith). Oxford: Oxford University Press.

Hassouneh-Phillips, D. and E. McNeff (2005) I thought I was less worthy: Low sexual and body esteem and increased vulnerability to intimate partner abuse in women with physical disabilities. Sexuality and Disability, 23(4), 227-240.

Hay, C. and M.M. Evans (2006) Violent victimization and involvement in delinquency: Examining predictions from general strain theory. Journal of Criminal Justice, 34(3), 261-274.

Heaton, P. (2006) Does religion really reduce crime? Journal of Law and Economics, 49(1), 147-172.

Heckman J (1978) Dummy endogenous variables in a simultaneous equation system, Econometrica, 46, 931-959.

Hentig, H. v. (1941) Remarks on the interaction of perpetrator and victim. Journal of Criminal Law, Criminology, and Police Science, 31, 303-309.

Hentig, H. v. (1948) The Criminal and His Victim. New Haven: Yale U. Press.

Hindelang, M. (1976) Criminal Victimization in Eight American Cities. Cambridge, MA: Ballinger. 
Hindelang, M.J., M.R. Gottfredson and J. Garofalo (1978) Victims of Personal Crime: An Empirical Foundation for a Theory of Personal Victimization. Cambridge: Ballinger.

Hirschi, T. (1969) Causes of Delinquency. Berkeley: University of California Press.

Hirschi, T. and R. Stark (1969) Hellfire and delinquency. Social Problems, 17, 202-213.

Hjalmarsson, R, M.L. Lindquist (2012) Like godfather, like son: Exploring the intergenerational nature of crime. Journal of Human Resources, 47(2), 550-582.

Jacobs, B.A., and R. Wright (2010) Bounded rationality, retaliation, and the spread of urban violence. Journal of Interpersonal Violence, 25(10), 1739-1766.

Jacques, S., and R. Wright (2008) The victimization-termination link. Criminology, 46(4), 1009-1038.

Jennings, W.G., A.R. Piquero and J.M. Reingle (2012) On the overlap between victimization and offending: A review of the literature. Aggression and Violent Behavior, 17, 1626.

Jensen, G.F and D. Brownfield (1986) Gender, lifestyles and victimization: Beyond routine activity theory. Violence and Victims, 1, 85-99.

Kim, J. (2008) The protective effects of religiosity on maladjustment among maltreated and nonmaltreated children. Child Abuse and Neglect, 32, 711-720.

Klevens, J., L.F. Duque, and C. Ramirez, C. (2002) The victim-offender overlap and routine activities: Results from a cross-sectional study in Bogota, Columbia. Journal of Interpersonal Violence, 17, 206-216.

Kubrin, C.E., and R. Weitzer (2003) Retaliatory homicide: Concentrated disadvantage and neighborhood culture. Social Problems, 50(2), 157-180.

Lauritsen, J.L., R.J. Sampson and J.H. Laub (1991) The link between offending and victimization among adolescents. Criminology, 29, 265-291.

Levitt, S.D., and S.A. Venkatesh (2000) An Economic Analysis of a Drug-Selling Gang's Finances. The Quarterly Journal of Economics, 115(3), 755 - 789.

Lochner, L. and E. Moretti (2004) The effect of education on crime: Evidence from prison inmates, arrests and self-Reports. American Economic Review, 94, 155-189.

Loureiro, M. and R. Alvarez (2012) Stigma, ex-convicts and labor markets. German Economic Review, 13(4), 470-486.

Maas, C., T. Herrenkohl and C. Sousa (2008) Review of research on child maltreatment and violence in youth, Trauma, Violence, and Abuse, 9(1), 56-67.

Machin, S., O. Marie and S. Vujić (2011) The crime reducing effect of education. Economic Journal, 121 (552), 463-484.

Maddala, G. S. (1983) Limited Dependent and Qualitative Variables in Econometrics, Cambridge: Cambridge University Press.

McAdams, R.H. and T.S. Ulen (2009) Behavioral Criminal Law and Economics. In: Criminal Law and Economics (ed. N. Garoupa), Cheltenham: Edward Elgar, 403-425.

McIntyre, S.G. and D.C. Lacombe (2012) Personal indebtedness, spatial effects and crime. Economics Letters, Volume 117(2),455-459.

Merton, R. (1938) Social structure and anomie. American Sociological Review, 3, 672-682.

Monfardini, C. and R. Radice (2008) Testing exogeneity in the bivariate Probit model: A Monte Carlo Study. Oxford Bulletin of Economics and Statistics, 70(2), 271-282.

Osgood, D. W., J.K. Wilson, P.M. O'Malley, J.G. Bachman, and L.D. Johnston (1996) Routine activities and individual deviant behavior. American Sociological Review, 61, 635-655. 
Ousey, G.C., P. Wilcox and S. Brummel (2008) Déjà vu all over again: Investigating temporal continuity of adolescent victimization. Journal of Quantitative Criminology, 24, 307-335.

Ousey, G.C., P. Wilcox and B.S. Fisher (2011) Something old, something new: Revisiting competing hypotheses of the victimization-offending relationship among adolescents. Journal of Quantitative Criminology, 27, 53-84.

Papadopoulos, G. (2011) The Relationship between Immigration Status and Victimization. Evidence from the British Crime Survey, mimeo, University of Essex, paper presented to the European Economic Association meeting in Oslo.

Peterson, D., T.J. Taylor and F.-A. Esbensen (2004) Gang membership and violent victimization. Justice Quarterly, 21 (4), 793-815.

Pichler, S. and D. Römer (2011) Juvenile law and recidivism in Germany - New evidence from the old continent. Discussion Paper Series No. 519, Department of Economics, University of Heidelberg.

Pichler, S. and D. Römer (2013) The young prisoner's dilemma: Juvenile recidivism in Germany, in: Lessons from the Economics of Crime: What Reduces Offending? (eds. P. Cook, S. Machin, O. Marie and G. Mastrobuoni), Cambridge: MIT Press.

Rowe, D.C. and D.P. Farrington (1997) The familial transmission of criminal convictions. Criminology, 35(1), 177-201.

Sampson, R.J. (1985) Neighborhood and crime: The structural determinants of personal victimization. Journal of Research in Crime and Delinquency, 22, 7-40.

Sampson, R.J., and J.L. Lauritsen (1990) Deviant lifestyles, proximity to crime and the offender-victim link in personal violence, Journal of Research in Crime and Delinquency, 27, 110-139.

Schreck, C.J., E.A. Stewart and B.S. Fisher (2006) Self-control, victimization, and their influence on risky lifestyles: A longitudinal analysis using panel data. Journal of Quantitative Criminology, 22, 319-340.

Schreck, C.J., E.A. Stewart and D.W. Osgood (2008) A Reappraisal of the overlap of violent offenders and victims. Criminology, 46(4), 871-904.

Shaffer, J.N. (2004) The Victim-Offender Overlap: Specifying the Role of Peer Groups. U.S. Department of Justice Report Document No 205126, also thesis at The Pennsylvania State University, December 2003.

Silver, E., A.R. Piquero, A.R. Jennings, G. Wesley, N.L. Piquero and M. Leiber (2011) Assesing the violent offending and violent victimization overlap among discharged psychiatric patients. Law and Human Behavior, 35(1), 49-59.

Simon, H.A. (1957) Models of Man, Social and Rational: Mathematical Essays on Rational Human Behavior in a Social Setting. New York: Wiley.

Simon, H.A. (1982) Models of Bounded Rationality. Vols. 1 and 2. Cambridge: MIT Press.

Simons, R.L., and C. H. Burt (2011) Learning to be bad: Adverse social conditions, social schemas and crime. Criminology, 49(2), 553-598.

Singer, S. (1981) Homogeneous victim-offender populations: A review and some research implications. Journal of Criminal Law and Criminology, 72, 779-88.

Sobel, R.S., and B.J. Osoba (2009) Youth gangs as pseudo-governments: Implications for violent crime. Southern Economic Journal, 75(4), 996-1018.

Sparks, R. F., Glen, A. G., \& Dodd, D. J. (1977) Surveying victims. New York: Wiley.

Van Dijk, J. J. and C.H. Steinmetz (1983) Victimization surveys: Beyond measuring the volume of crime. Victimology, 8, 291-309.

Vollaard, B. and J.C Van Ours (2011) Does regulation of built-in security reduce crime? Evidence from a natural experiment. Economic Journal 121(552), 485-504. 
Widom, C.S. (1989a) The cycle of violence. Science, 244, 160-166.

Widom, C.S. (1989b) Child abuse, neglect, and violent criminal behavior. Criminology, 27, 251-271.

Wilcox, P., D.C. May and S.D. Roberts (2006) Student weapon possession and the "fear and victimization hypothesis": Unraveling the temporal order. Justice Quarterly, (23), 502-529.

Wilde, J. (2000) Identification of multiple equation Probit models with endogenous dummy regressors. Economics Letters, 69, 309-312.

Winden, F. v. and E. Ash (2012) On the behavioral economics of crime. Review of Law and Economics, 8, 181-213.

Wittebrood, K., and P. Nieuwbeerta (1999) Wages of sin? The link between offending, lifestyle and violent victimization. European Journal of Criminal Policy and Research, 7, 63-80.

Wolfgang, M.E. (1958) Patterns in criminal homicide. New York: Wiley.

Wooldridge, J. M. (2010) Econometric Analysis of Cross Section and Panel Data, $2^{\text {nd }}$ ed. Cambridge, MA: The MIT Press.

Yun, I., J.D. Ball and H. Lim (2011) Disentangling the relationship between child maltreatment and violent delinquency: Using a nationally representative sample. Journal of Interpersonal Violence, 26(1), 88-110. 
Table 1: Descriptive Statistics

\begin{tabular}{|c|c|c|c|c|c|}
\hline Variable & Obs & Mean & Std. Dev. & Min & Max \\
\hline Offending (conviction) & 960 & 0.070833 & 0.25668 & 0 & 1 \\
\hline Victimization & 960 & 0.278125 & 0.448309 & 0 & 1 \\
\hline \multicolumn{6}{|l|}{$\begin{array}{l}\text { Economic status and } \\
\text { well-being }\end{array}$} \\
\hline No school & 960 & 0.087500 & 0.282713 & 0 & 1 \\
\hline Hauptschule & 960 & 0.422917 & 0.494279 & 0 & 1 \\
\hline Low/no school degree & 960 & 0.535417 & 0.499004 & 0 & 1 \\
\hline Abitur or University & 960 & 0.235417 & 0.424480 & 0 & 1 \\
\hline Unemployed & 960 & 0.203125 & 0.402534 & 0 & 1 \\
\hline Good health condition & 960 & 0.797917 & 0.401763 & 0 & 1 \\
\hline Excessive indebtedess & 960 & 0.061458 & 0.240294 & 0 & 1 \\
\hline \multicolumn{6}{|c|}{$\begin{array}{l}\text { Routine Activity/ } \\
\text { Lifestyle }\end{array}$} \\
\hline 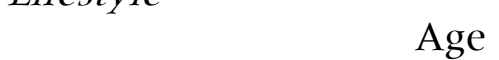 & 960 & 37.8 & 120.964 & 18 & 69 \\
\hline Male & 960 & 0.878125 & 0.327311 & 0 & 1 \\
\hline Married & 960 & 0.603125 & 0.489504 & 0 & 1 \\
\hline Has children & 960 & 0.601042 & 0.489939 & 0 & 1 \\
\hline Foreign citizenship & 960 & 0.116667 & 0.321190 & 0 & 1 \\
\hline Muslim & 960 & 0.015625 & 0.124084 & 0 & 1 \\
\hline No confession & 960 & 0.271875 & 0.445157 & 0 & 1 \\
\hline Village & 960 & 0.378125 & 0.485171 & 0 & 1 \\
\hline \multicolumn{6}{|l|}{$\begin{array}{l}\text { Peer, family and sub- } \\
\text { cultural influence }\end{array}$} \\
\hline $\begin{array}{r}\text { Has more than } 20 \text { loose } \\
\text { friends }\end{array}$ & 960 & 0.551042 & 0.497647 & 0 & 1 \\
\hline Has no close friend & 960 & 0.063542 & 0.244061 & 0 & 1 \\
\hline Has one close friend & 960 & 0.137500 & 0.344553 & 0 & 1 \\
\hline $\begin{array}{l}\text { Criminal record of } \\
\text { parents or siblings }\end{array}$ & 960 & 0.054167 & 0.226464 & 0 & 1 \\
\hline $\begin{array}{r}\text { Parents divorced or } \\
\text { separated }\end{array}$ & 960 & 0.102083 & 0.302915 & 0 & 1 \\
\hline \multicolumn{6}{|l|}{ Low self control } \\
\hline $\begin{array}{r}\text { Serious drug or alcohol } \\
\text { problem }\end{array}$ & 960 & 0.021875 & 0.146351 & 0 & 1 \\
\hline
\end{tabular}

Notes: Descriptive statistics for adult non-pupils (age $\geq 18$ ). Source: Author's calculation based on the German Crime Survey (see Entorf et al., 2008, for details). 
Table 2: Victimization of offenders and non-offenders

\begin{tabular}{lccc}
\hline & \multicolumn{3}{c}{ Share of victims (\%) among ... } \\
\cline { 2 - 4 } & $\begin{array}{c}\text { Non-offenders } \\
\text { without any } \\
\text { conviction }\end{array}$ & $\begin{array}{c}\text { Offenders in } \\
\text { population survey }\end{array}$ & $\begin{array}{c}\text { Offenders in prison } \\
\text { population }\end{array}$ \\
Victimization... & 25.9 & 52.9 & 43.1 \\
\hline$\ldots$ of any crime & 23.1 & 42.7 & 24.2 \\
$\ldots$ of petty crime & 2.8 & 10.3 & 18.8 \\
$\ldots$ of severe crime & 892 & 68 & 1.239 \\
\hline $\begin{array}{l}\text { Number of } \\
\text { observations }\end{array}$ & & 68 & \\
\hline
\end{tabular}

Data: German Crime Survey and German Inmate Survey (GIS). Descriptive statistics are for adult non-pupils (age $\geq 18$ ).

Table 3: Offending by victims and non-victims

\begin{tabular}{lcccc}
\hline & \multicolumn{4}{c}{ Share of offenders } \\
\cline { 2 - 5 } Type of offense & $\begin{array}{l}\ldots \text { in non- } \\
\text { victimized } \\
\text { subsample }\end{array}$ & $\begin{array}{c}\ldots \text { in } \\
\text { victimized } \\
\text { subsample }\end{array}$ & $\begin{array}{c}\text {.. among } \\
\text { victims of } \\
\text { severe crime }\end{array}$ & $\begin{array}{c}\text {. } \\
\text { victims omong } \\
\text { petty crime }\end{array}$ \\
\hline Any crime & 4.6 & 13.5 & 21.9 & 12.3 \\
Property crime & 2.2 & 6.7 & 9.4 & 6.4 \\
Violent crime & 1.4 & 3.0 & 6.3 & 2.6 \\
Other crime & 1.3 & 4.5 & 6.3 & 4.3 \\
\hline $\begin{array}{l}\text { Number of } \\
\text { observations }\end{array}$ & 693 & 267 & 32 & 235
\end{tabular}

Data: German Crime Survey. Descriptive statistics are for adult non-pupils (age $\geq 18$ ). Note that columns do not sum up to marginal values because some respondents had convictions for more than one crime. 


\begin{tabular}{|c|c|c|c|c|}
\hline & \multicolumn{4}{|c|}{ Marginal Effects of univariate Probit parameter estimates } \\
\hline & \multicolumn{2}{|c|}{ Univariate Probit $(4 a)$} & \multicolumn{2}{|c|}{ Univariate Probit $(4 \mathrm{~b})$} \\
\hline & Offending & Victimization & Offending & Victimization \\
\hline Offending & - & - & - & $0.258(0.068)^{* * *}$ \\
\hline Victimization & - & - & $0.055(0.019)^{* * *}$ & - \\
\hline $\begin{array}{l}\text { Economic status and } \\
\text { Well-being }\end{array}$ & & & & \\
\hline Low/no school degree & $0.028(0.014)^{* *}$ & $-0.114(0.031)^{* * *}$ & $0.031(0.013)^{* *}$ & $-0.125(0.031)^{* * *}$ \\
\hline Unemployed & $0.004(0.018)$ & $-0.072(0.036)^{* *}$ & $0.008(0.018)$ & $-0.073(0.036)^{* *}$ \\
\hline Good health condition & $-0.022(0.189)$ & $-0.100(0.041)^{* *}$ & $-0.013(0.017)$ & $-0.095(0.041)^{* *}$ \\
\hline Excessive indebtedess & $0.134(0.052)^{* * *}$ & $0.074(0.068)$ & $0.121(0.050)^{* *}$ & $0.027(0.066)$ \\
\hline \multicolumn{5}{|l|}{$\begin{array}{l}\text { Routine Activity/ } \\
\text { Lifestyle }\end{array}$} \\
\hline Age & $0.002(0.004)$ & $0.008(0.009)$ & $0.002(0.004)$ & $0.007(0.009)$ \\
\hline Age-sq. & $-0.000(0.000)$ & $-0.000(0.000)$ & $-0.000(0.000)$ & $-0.000(0.000)$ \\
\hline Male & $0.050(0.010)^{* * *}$ & $0.066(0.043)$ & $0.046(0.010)^{* * *}$ & $0.052(0.044)$ \\
\hline Married & $-0.006(0.018)$ & $-0.094(0.043)^{* *}$ & $-0.001(0.017)$ & $-0.092(0.043)^{* *}$ \\
\hline Has children & $0.004(0.018)$ & $-0.044(0.044)$ & $0.004(0.017)$ & $-0.046(0.045)$ \\
\hline Migration background & $-0.023(0.016)$ & $-0.034(0.046)$ & $-0.023(0.015)$ & $-0.027(0.046)$ \\
\hline Muslim & $0.161(0.126)$ & $0.149(0.144)$ & $0.150(0.122)$ & $0.103(0.141)$ \\
\hline No confession & $-0.028(0.017)$ & $0.065(0.035)^{*}$ & $-0.021(0.016)$ & $0.056(0.035)^{*}$ \\
\hline Village & $-0.018(0.012)$ & $-0.014(0.030)$ & $-0.016(0.012)$ & $-0.007(0.031)$ \\
\hline \multicolumn{5}{|l|}{$\begin{array}{l}\text { Peer, family and sub- } \\
\text { cultural influence }\end{array}$} \\
\hline $\begin{array}{r}\text { Has more than } 20 \\
\text { friends }\end{array}$ & $0.000(0.013)$ & $0.077(0.029)^{\star \star *}$ & $-0.003(0.012)$ & $0.078(0.029)^{* * *}$ \\
\hline $\begin{array}{r}\text { Has no single close } \\
\text { friend }\end{array}$ & $-0.018(0.019)$ & $0.037(0.063)$ & $-0.015(0.019)$ & $0.042(0.064)$ \\
\hline Has one close friend & $-0.001(0017)$ & $-0.054(0.041)$ & $-0.000(0017)$ & $-0.054(0.041)$ \\
\hline $\begin{array}{l}\text { Criminal record of } \\
\text { parents or siblings }\end{array}$ & $0.090(0.044)^{* *}$ & $0.140(0.074)^{*}$ & $0.074(0.041)^{*}$ & $0.105(0.074)$ \\
\hline $\begin{array}{r}\text { Parents divorced or } \\
\text { separated }\end{array}$ & $0.102(0.037)^{* * *}$ & $0.061(0.052)$ & $0.093(0.035)^{* * *}$ & $0.029(0.052)$ \\
\hline \multicolumn{5}{|l|}{ Low self control } \\
\hline $\begin{array}{r}\text { Serious drug or alcohol } \\
\text { problem }\end{array}$ & $0.041(0.054)$ & $0.047(0.106)$ & $0.033(0.051)$ & $0.024(0.104)$ \\
\hline Log-Likelihood & -199.83 & -534.06 & -193.66 & -525.99 \\
\hline Pseudo- $\mathrm{R}^{2}$ & 0.186 & 0.059 & 0.211 & 0.073 \\
\hline $\begin{array}{l}\text { Number of } \\
\text { observations }\end{array}$ & 960 & 960 & 960 & 960 \\
\hline
\end{tabular}

Notes: Standard errors in parentheses; $\left.{ }^{* * *}\right),{ }^{* *}$ ) and ${ }^{*}$ ) represent significance at the 1,5 and 10 percent level, respectively; significance of rho is tested using a likelihood-ratio test. Marginal effects are obtained as average partial effects, standard errors are computed using the delta method. See Table 1 for data. 
Table 5: Seemingly unrelated bivariate Probit estimation, model (1)

\begin{tabular}{|c|c|c|c|c|}
\hline & \multicolumn{4}{|c|}{ Marginal Effects of bivariate Probit parameter estimates } \\
\hline & \multicolumn{2}{|c|}{$\begin{array}{l}\text { Seemingly unrelated bivariate } \\
\text { Probit }(5 a)\end{array}$} & \multicolumn{2}{|c|}{$\begin{array}{l}\text { Seemingly unrelated bivariate } \\
\text { Probit }(5 b)\end{array}$} \\
\hline & Offending & Victimization & Offending & Victimization \\
\hline \multicolumn{5}{|l|}{$\begin{array}{l}\text { Economic status and } \\
\text { well-being }\end{array}$} \\
\hline Low/no school degree & $0.027(0.014)^{*}$ & $-0.114(0.031)^{* * *}$ & $0.030(0.014)^{* *}$ & $-0.109(0.030)^{* * *}$ \\
\hline Unemployed & $0.004(0.018)$ & $-0.072(0.036)^{* *}$ & - & $-0.072(0.036)^{* *}$ \\
\hline Good health condition & $-0.020(0.019)$ & $-0.101(0.041)^{* *}$ & - & $-0.105(0.040)^{* * *}$ \\
\hline Excessive indebtedess & $0.133(0.052)^{* * *}$ & $0.075(0.068)$ & $0.150(0.053)^{* * *}$ & - \\
\hline \multicolumn{5}{|l|}{$\begin{array}{l}\text { Routine Activity/ } \\
\text { Lifestyle }\end{array}$} \\
\hline Age & $0.002(0.004)$ & $0.008(0.009)$ & $0.001(0.004)$ & $0.005(0.008)$ \\
\hline Age-sq. & $-0.000(0.000)$ & $-0.000(0.000)$ & $-0.000(0.000)$ & $-0.000(0.000)$ \\
\hline Male & $0.050(0.010)^{* * *}$ & $0.065(0.043)$ & $0.053(0.011)^{* * *}$ & $0.069(0.042)^{*}$ \\
\hline Married & $-0.006(0.018)$ & $-0.092(0.043)^{* *}$ & - & $-0.112(0.037)^{* * *}$ \\
\hline Has children & $0.002(0.018)$ & $-0.045(0.044)$ & - & - \\
\hline Migration background & $-0.025(0.016)$ & $-0.034(0.046)$ & - & - \\
\hline Muslim & $0.171(0.128)$ & $0.145(0.143)$ & - & - \\
\hline No confession & $0.026(0.017)$ & $0.065(0.035)^{*}$ & $0.029(0.017)^{*}$ & $0.062(0.034)^{*}$ \\
\hline Village & $-0.018(0.013)$ & $-0.013(0.031)$ & - & - \\
\hline \multicolumn{5}{|l|}{$\begin{array}{l}\text { Peer, family and sub- } \\
\text { cultural influence }\end{array}$} \\
\hline $\begin{array}{r}\text { Has more than } 20 \\
\text { friends }\end{array}$ & $0.001(0.013)$ & $0.077(0.029)^{* * *}$ & - & $0.076(0.029)^{* * *}$ \\
\hline $\begin{array}{r}\text { Has no single close } \\
\text { friend }\end{array}$ & $-0.014(0.021)$ & $0.037(0.063)$ & - & - \\
\hline Has one close friend & $-0.003(0.017)$ & $-0.055(0.041)$ & - & - \\
\hline $\begin{array}{l}\text { Criminal record of } \\
\text { parents or siblings }\end{array}$ & $0.091(0.045)^{* *}$ & $0.140(0.074)^{*}$ & $0.102(0.047)^{* *}$ & $0.162(0.073)^{* *}$ \\
\hline $\begin{array}{r}\text { Parents divorced or } \\
\text { separated }\end{array}$ & $0.102(0.037)^{* * *}$ & $0.061(0.053)$ & $0.098(0.036)^{* * *}$ & - \\
\hline \multicolumn{5}{|l|}{ Low self control } \\
\hline $\begin{array}{r}\text { Serious drug or alcohol } \\
\text { problem }\end{array}$ & $0.038(0.054)$ & $0.045(0.106)$ & - & - \\
\hline$\rho$ & \multicolumn{2}{|c|}{$0.306(0.083)$} & \multicolumn{2}{|c|}{$0.314(0.081)$} \\
\hline $\begin{array}{l}\text { Likelihood-ratio test of } \\
\rho=0 \quad(p \text {-value })\end{array}$ & \multicolumn{2}{|c|}{$\begin{array}{l}12.43^{* * *} \\
(0.000)\end{array}$} & \multicolumn{2}{|c|}{$\begin{array}{l}13.50^{* * *} \\
(0.000)\end{array}$} \\
\hline Log-Likelihood & \multicolumn{2}{|c|}{-727.67} & \multicolumn{2}{|c|}{-735.65} \\
\hline $\begin{array}{l}\text { Number of } \\
\text { observations }\end{array}$ & \multicolumn{2}{|c|}{960} & \multicolumn{2}{|c|}{960} \\
\hline
\end{tabular}

Notes: Standard errors in parentheses; $\left.{ }^{* *}\right),{ }^{* *}$ ) and ${ }^{*}$ ) represent significance at the 1,5 and 10 percent level, respectively; significance of rho is tested using a likelihood-ratio test. Marginal effects are obtained as average partial effects, standard errors are computed using the delta method. See Table 1 for data. 
Table 6: Recursive bivariate Probit estimation, model (2)

\begin{tabular}{|c|c|c|c|c|}
\hline & \multicolumn{4}{|c|}{ Marginal Effects of bivariate Probit parameter estimates } \\
\hline & \multicolumn{2}{|c|}{ Recursive bivariate Probit (6a) } & \multicolumn{2}{|c|}{ Recursive bivariate Probit (6b) } \\
\hline & Offending & Victimization & Offending & Victimization \\
\hline Offending & - & $0.663(0.075)^{* * *}$ & - & $0.619(0.108)^{* * *}$ \\
\hline $\begin{array}{l}\text { Economic status and } \\
\text { well-being }\end{array}$ & & & & \\
\hline Low/no school degree & $0.034(0.014)^{* * *}$ & $-0.134(0.030)^{* * *}$ & $0.034(0.014)^{* *}$ & $-0.136(0.030)^{* * *}$ \\
\hline Unemployed & $0.011(0.019)$ & $-0.074(0.036)^{* *}$ & $0.010(0.019)$ & $-0.075(0.036)^{* *}$ \\
\hline $\begin{array}{r}\text { Good health } \\
\text { condition }\end{array}$ & $-0.024(0.019)$ & $-0.082(0.040)^{* *}$ & $-0.024(0.019)$ & $-0.081(0.040)^{* *}$ \\
\hline Excessive indebtedess & $0.150(0.053)^{* * *}$ & $-0.062(0.060)$ & $0.137(0.050)^{* * *}$ & - \\
\hline \multicolumn{5}{|l|}{$\begin{array}{l}\text { Routine Activity/ } \\
\text { Lifestyle }\end{array}$} \\
\hline Age & $0.003(0.004)$ & $0.004(0.008)$ & $0.003(0.004)$ & $0.004(0.008)$ \\
\hline Age-sq. & $-0.000(0.000)$ & $-0.000(0.000)$ & $-0.000(0.000)$ & $-0.000(0.000)$ \\
\hline Male & $0.052(0.010)^{* * *}$ & $0.041(0.045)$ & $0.051(0.010)^{* * *}$ & $0.043(0.045)$ \\
\hline Married & $-0.006(0.016)$ & $-0.106(0.038)^{* * *}$ & $-0.006(0.016)$ & $-0.104(0.038)^{* * *}$ \\
\hline No confession & $0.031(0.017)^{*}$ & $0.037(0.034)$ & $0.030(0.017)^{*}$ & $0.040(0.034)$ \\
\hline \multicolumn{5}{|l|}{$\begin{array}{l}\text { Peer, family and sub- } \\
\text { cultural influence }\end{array}$} \\
\hline $\begin{array}{r}\text { Has more than } 20 \\
\text { friends }\end{array}$ & $-0.007(0.013)$ & $0.076(0.029)^{* * * *}$ & $-0.006(0.013)$ & $0.078(0.029)^{* * *}$ \\
\hline $\begin{array}{l}\text { Criminal record of } \\
\text { parents or siblings }\end{array}$ & $0.093(0.045)^{* *}$ & $0.031(0.071)$ & $0.095(0.045)^{* *}$ & $0.035(0.074)$ \\
\hline $\begin{array}{r}\text { Parents divorced or } \\
\text { separated }\end{array}$ & $0.099(0.036)^{* * *}$ & $-0.026(0.049)$ & $0.100(0.035)^{* * *}$ & $-0.017(0.050)$ \\
\hline$\rho$ & \multicolumn{2}{|c|}{$-0.683(0.391)$} & \multicolumn{2}{|c|}{$-0.579(0.246)$} \\
\hline $\begin{array}{l}\text { Likelihood-ratio test } \\
\text { of } \rho=0 \quad(p \text {-value })\end{array}$ & \multicolumn{2}{|c|}{$\begin{array}{l}4.31^{* *} \\
(0.038)\end{array}$} & \multicolumn{2}{|c|}{$\begin{array}{c}3.48^{*} \\
(0.062)\end{array}$} \\
\hline Log-Likelihood & \multicolumn{2}{|c|}{-729.45} & \multicolumn{2}{|c|}{-729.91} \\
\hline $\begin{array}{l}\text { Number of } \\
\text { observations }\end{array}$ & \multicolumn{2}{|c|}{960} & \multicolumn{2}{|c|}{960} \\
\hline
\end{tabular}

Notes: Standard errors in parentheses; $\left.{ }^{* * *}\right),{ }^{* *}$ ) and $\left.{ }^{*}\right)$ represent significance at the 1,5 and 10 percent level, respectively; significance of rho is tested using a likelihood-ratio test. Marginal effects are obtained as average partial effects, standard errors are computed using the delta method. See Table 1 for data. 
Table 7: Recursive bivariate Probit estimation, model (3)

\begin{tabular}{|c|c|c|c|c|}
\hline & \multicolumn{4}{|c|}{ Marginal Effects of bivariate Probit parameter estimates } \\
\hline & \multicolumn{2}{|c|}{ Recursive bivariate Probit $(7 a)$} & \multicolumn{2}{|c|}{ Recursive bivariate Probit $(7 \mathrm{~b})$} \\
\hline & Offending & Victimization & Offending & Victimization \\
\hline Victimization & $-0.002(0.127)$ & - & $0.223(0.384)$ & - \\
\hline $\begin{array}{l}\text { Economic status and } \\
\text { well-being }\end{array}$ & & & & \\
\hline Low/no school degree & $0.030(0.017)^{*}$ & $-0.114(0.030)$ & $0.048(0.033)$ & $-0.110(0.031)^{* * *}$ \\
\hline Unemployed & $0.007(0.021)$ & $-0.070(0.036)^{*}$ & $0.019(0.026)$ & $-0.070(0.036)^{*}$ \\
\hline $\begin{array}{r}\text { Good health } \\
\text { condition }\end{array}$ & $-0.021(0.030)$ & $-0.103(0.041)^{* *}$ & - & $-0.103(0.040)^{* * *}$ \\
\hline Excessive indebtedess & $0.146(0.066)^{* *}$ & $0.070(0.067)$ & $0.124(0.054)^{* *}$ & $0.067(0.067)$ \\
\hline \multicolumn{5}{|l|}{$\begin{array}{l}\text { Routine Activity/ } \\
\text { Lifestyle }\end{array}$} \\
\hline Age & $0.003(0.004)$ & $0.005(0.008)$ & $0.002(0.004)$ & $0.006(0.008)$ \\
\hline Age-sq. & $-0.000(0.000)$ & $-0.000(0.000)$ & $-0.000(0.000)$ & $-0.000(0.000)$ \\
\hline Male & $0.052(0.026)^{* *}$ & $0.070(0.041)^{*}$ & $0.053(0.024)^{* *}$ & $0.070(0.042)^{*}$ \\
\hline Married & $-0.007(0.026)$ & $-0.112(0.038)^{* * *}$ & $0.008(0.024)$ & $-0.115(0.038)^{* * *}$ \\
\hline No confession & $0.026(0.024)$ & $0.061(0.034)^{*}$ & $0.017(0.017)$ & $0.064(0.035)^{*}$ \\
\hline \multicolumn{5}{|l|}{$\begin{array}{l}\text { Peer, family and sub- } \\
\text { cultural influence }\end{array}$} \\
\hline $\begin{array}{r}\text { Has more than } 20 \\
\text { friends }\end{array}$ & $-0.001(0.018)$ & $0.078(0.029)^{* * *}$ & $-0.013(0.021)$ & $0.075(0.030)^{* *}$ \\
\hline $\begin{array}{l}\text { Criminal record of } \\
\text { parents or siblings }\end{array}$ & $0.096(0.071)$ & $0.142(0.074)^{*}$ & $0.060(0.048)$ & $0.142(0.074)^{*}$ \\
\hline $\begin{array}{r}\text { Parents divorced or } \\
\text { separated }\end{array}$ & $0.101(0.047)^{* *}$ & $0.057(0.052)$ & $0.088(0.035)^{* *}$ & $0.058(0.052)$ \\
\hline$\rho$ & \multicolumn{2}{|c|}{$0.324(0.771)$} & \multicolumn{2}{|c|}{$-0.458(0.729)$} \\
\hline $\begin{array}{l}\text { Likelihood-ratio test } \\
\text { of } \rho=0 \quad(p \text {-value ) }\end{array}$ & \multicolumn{2}{|c|}{$\begin{array}{c}0.113 \\
(0.737)\end{array}$} & \multicolumn{2}{|c|}{$\begin{array}{c}0.271 \\
(0.602)\end{array}$} \\
\hline Log-Likelihood & \multicolumn{2}{|c|}{-733.45} & \multicolumn{2}{|c|}{-733.71} \\
\hline $\begin{array}{l}\text { Number of } \\
\text { observations }\end{array}$ & \multicolumn{2}{|c|}{960} & \multicolumn{2}{|c|}{960} \\
\hline
\end{tabular}

Notes: Standard errors in parentheses; $\left.{ }^{* * *}\right),{ }^{* *}$ ) and $\left.{ }^{*}\right)$ represent significance at the 1,5 and 10 percent level, respectively; significance of rho is tested using a likelihood-ratio test. Marginal effects are obtained as average partial effects, standard errors are computed using the delta method. See Table 1 for data. 
Table 8: Recursive bivariate Probit estimation, model (2), sensitivity analysis

\begin{tabular}{|c|c|c|c|c|}
\hline & \multicolumn{4}{|c|}{ Marginal Effects of Bivariate Probit parameter estimates } \\
\hline & \multicolumn{2}{|c|}{ Recursive bivariate Probit (8a) } & \multicolumn{2}{|c|}{ Recursive bivariate Probit (8b) } \\
\hline & Offending & Victimization & Offending & Victimization \\
\hline Offending & - & $0.646(0.070)^{* * *}$ & - & $0.633(0.077)^{* * *}$ \\
\hline $\begin{array}{l}\text { Economic status and } \\
\text { well-being } \\
\text { Low/no school } \\
\text { degree }\end{array}$ & $0.034(0.014)^{* *}$ & $-0.137(0.030)^{* * *}$ & $0.034(0.013)^{* * *}$ & $-0.137(0.030)^{* * *}$ \\
\hline Unemployed & $0.011(0.019)$ & $-0.078(0.036)^{* *}$ & - & $-0.073(0.035)^{* *}$ \\
\hline $\begin{array}{r}\text { Good health } \\
\text { condition }\end{array}$ & $-0.024(0.019)$ & $-0.079(0.040)^{* *}$ & - & $-0.093(0.039)^{* *}$ \\
\hline $\begin{array}{r}\text { Excessive } \\
\text { indebtedess }\end{array}$ & $0.134(0.049)^{* * *}$ & - & $0.152(0.051)^{* * *}$ & - \\
\hline \multicolumn{5}{|l|}{$\begin{array}{l}\text { Routine Activity/ } \\
\text { Lifestyle }\end{array}$} \\
\hline Age & $0.003(0.004)$ & $0.005(0.008)$ & $0.001(0.003)$ & $0.006(0.008)$ \\
\hline Age-sq. & $-0.000(0.000)$ & $-0.000(0.000)$ & $-0.000(0.000)$ & $-0.000(0.000)$ \\
\hline Male & $0.052(0.010)^{* * *}$ & - & $0.054(0.010)^{* * * *}$ & - \\
\hline Married & $-0.006(0.016)$ & $-0.113(0.037)^{* * *}$ & - & $-0.116(0.036)^{* * *}$ \\
\hline No confession & $0.035(0.017)^{* *}$ & - & $0.038(0.017)^{* *}$ & - \\
\hline \multicolumn{5}{|l|}{$\begin{array}{l}\text { Peer, family and } \\
\text { sub-cultural } \\
\text { influence }\end{array}$} \\
\hline $\begin{array}{r}\text { Has more than } 20 \\
\text { friends }\end{array}$ & $-0.007(0.013)$ & $0.076(0.029)^{* * *}$ & - & $0.073(0.029)^{* * *}$ \\
\hline $\begin{array}{l}\text { Criminal record of } \\
\text { parents or siblings }\end{array}$ & $0.102(0.044)^{* *}$ & - & $0.108(0.045)^{* *}$ & - \\
\hline $\begin{array}{r}\text { Parents divorced or } \\
\text { separated }\end{array}$ & $0.095(0.034)^{* * *}$ & - & $0.101(0.035)^{* * *}$ & - \\
\hline$\rho$ & \multicolumn{2}{|c|}{$-0.637(0.185)$} & \multicolumn{2}{|c|}{$-0.602(0.298)$} \\
\hline $\begin{array}{l}\text { Likelihood-ratio test } \\
\text { of } \rho=0 \quad(p \text {-value ) }\end{array}$ & \multicolumn{2}{|c|}{$\begin{array}{l}7.723^{* * *} \\
(0.006)\end{array}$} & \multicolumn{2}{|c|}{$\begin{array}{l}6.940^{* * *} \\
(0.008)\end{array}$} \\
\hline Log-Likelihood & \multicolumn{2}{|c|}{-731.27} & \multicolumn{2}{|c|}{-732.74} \\
\hline $\begin{array}{l}\text { Number of } \\
\text { observations }\end{array}$ & \multicolumn{2}{|c|}{960} & \multicolumn{2}{|c|}{960} \\
\hline
\end{tabular}

Notes: Standard errors in parentheses; $\left.{ }^{* * *}\right),{ }^{* *}$ ) and ${ }^{*}$ ) represent significance at the 1,5 and 10 percent level, respectively; significance of rho is tested using a likelihood-ratio test. Marginal effects are obtained as average partial effects, standard errors are computed using the delta method. See Table 1 for data. 
Table 9: Recursive bivariate Probit estimation, model (3), sensitivity analysis I

\begin{tabular}{|c|c|c|c|c|}
\hline & \multicolumn{4}{|c|}{ Marginal Effects of Bivariate Probit parameter estimates } \\
\hline & \multicolumn{2}{|c|}{ Recursive bivariate Probit (9a) } & \multicolumn{2}{|c|}{ Recursive bivariate Probit $(9 \mathrm{~b})$} \\
\hline & Offending & Victimization & Offending & Victimization \\
\hline Victimization & $0.141(0.174)$ & - & $0.149(0.181)$ & - \\
\hline $\begin{array}{l}\text { Economic status and } \\
\text { well-being }\end{array}$ & & & & \\
\hline $\begin{array}{r}\text { Low/no school } \\
\text { degree }\end{array}$ & $0.041(0.021)^{* *}$ & $-0.111(0.030)^{* * *}$ & $0.042(0.020)^{* *}$ & $-0.106(0.030)^{* * *}$ \\
\hline Unemployed & - & $-0.067(0.037)^{*}$ & - & $-0.067(0.037)^{*}$ \\
\hline $\begin{array}{r}\text { Good health } \\
\text { condition }\end{array}$ & - & $-0.103(0.040)^{* *}$ & - & $-0.112(0.040)^{* * *}$ \\
\hline $\begin{array}{r}\text { Excessive } \\
\text { indebtedess }\end{array}$ & $0.133(0.053)^{* *}$ & $0.068(0.067)$ & $0.140(0.051)^{* * *}$ & - \\
\hline \multicolumn{5}{|l|}{$\begin{array}{l}\text { Routine Activity/ } \\
\text { Lifestyle }\end{array}$} \\
\hline Age & $0.001(0.003)$ & $0.006(0.008)$ & $0.001(0.003)$ & $0.006(0.008)$ \\
\hline Age-sq. & $-0.000(0.000)$ & $-0.000(0.000)$ & $-0.000(0.000)$ & $-0.000(0.000)$ \\
\hline Male & $0.049(0.013)^{* * *}$ & $0.070(0.041)^{*}$ & $0.050(0.013)^{* * *}$ & $0.069(0.042)^{*}$ \\
\hline Married & - & $-0.113(0.038)^{* * *}$ & - & $-0.115(0.038)^{* * *}$ \\
\hline No confession & - & $0.067(0.035)^{*}$ & - & $0.068(0.035)^{*}$ \\
\hline \multicolumn{5}{|l|}{$\begin{array}{l}\text { Peer, family and } \\
\text { sub-cultural } \\
\text { influence }\end{array}$} \\
\hline $\begin{array}{r}\text { Has more than } 20 \\
\text { friends }\end{array}$ & - & $0.074(0.030)^{* *}$ & - & $0.072(0.030)^{* *}$ \\
\hline $\begin{array}{l}\text { Criminal record of } \\
\text { parents or siblings }\end{array}$ & $0.072(0.046)^{*}$ & $0.142(0.074)^{*}$ & $0.070(0.046)$ & $0.160(0.074)^{* *}$ \\
\hline $\begin{array}{r}\text { Parents divorced or } \\
\text { separated }\end{array}$ & $0.091(0.036)^{* * * *}$ & $0.058(0.052)$ & $0.096(0.036)^{* * *}$ & - \\
\hline$\rho$ & \multicolumn{2}{|c|}{$-0.273(0.508)$} & \multicolumn{2}{|c|}{$-0.290(0.470)$} \\
\hline $\begin{array}{l}\text { Likelihood-ratio test } \\
\text { of } \rho=0 \quad(p \text {-value })\end{array}$ & \multicolumn{2}{|c|}{$\begin{array}{c}0.308 \\
(0.579)\end{array}$} & \multicolumn{2}{|c|}{$\begin{array}{c}0.367 \\
(0.553)\end{array}$} \\
\hline Log-Likelihood & \multicolumn{2}{|c|}{-735.18} & \multicolumn{2}{|c|}{-736.40} \\
\hline $\begin{array}{l}\text { Number of } \\
\text { observations }\end{array}$ & \multicolumn{2}{|c|}{960} & \multicolumn{2}{|c|}{960} \\
\hline
\end{tabular}

Notes: Standard errors in parentheses; $\left.{ }^{* * *}\right),{ }^{* *}$ ) and $\left.{ }^{*}\right)$ represent significance at the 1,5 and 10 percent level, respectively; significance of rho is tested using a likelihood-ratio test. Marginal effects are obtained as average partial effects, standard errors are computed using the delta method. See Table 1 for data. 
Table 10: Recursive bivariate Probit estimation, model (3), sensitivity analysis II

\begin{tabular}{|c|c|c|c|c|}
\hline & \multicolumn{4}{|c|}{ Marginal Effects of Bivariate Probit parameter estimates } \\
\hline & \multicolumn{2}{|c|}{$\begin{array}{l}\text { a) Recursive bivariate Probit } \\
\text { (10a) }\end{array}$} & \multicolumn{2}{|c|}{$\begin{array}{l}\text { b) Recursive bivariate Probit } \\
\qquad(10 \mathrm{~b})\end{array}$} \\
\hline & Offending & Victimization & Offending & Victimization \\
\hline Victimization & $0.365(0.159)^{* *}$ & - & $0.377(0.158)^{* *}$ & - \\
\hline $\begin{array}{l}\text { Economic status and } \\
\text { well-being }\end{array}$ & & & & \\
\hline Low/no school degree & $0.063(0.022)^{* * *}$ & $-0.109(0.030)^{* * *}$ & $0.064(0.021)^{* * *}$ & $-0.104(0.030)^{* * * *}$ \\
\hline Unemployed & - & $-0.060(0.036)^{*}$ & - & $-0.059(0.036)^{*}$ \\
\hline $\begin{array}{r}\text { Good health } \\
\text { condition }\end{array}$ & - & $-0.102(0.039)^{* * *}$ & - & $-0.109(0.039)^{* * *}$ \\
\hline Excessive indebtedess & $0.133(0.052)^{* * *}$ & $0.059(0.066)$ & $0.148(0.050)^{* * *}$ & - \\
\hline \multicolumn{5}{|l|}{$\begin{array}{l}\text { Routine Activity/ } \\
\text { Lifestyle }\end{array}$} \\
\hline Age & $0.002(0.004)$ & $0.007(0.008)$ & $0.002(0.004)$ & $0.0076(0.008)$ \\
\hline Age-sq. & $-0.000(0.000)$ & $-0.000(0.000)$ & $-0.000(0.000)$ & $-0.000(0.000)$ \\
\hline Male & $0.061(0.018)^{* * *}$ & $0.070(0.042)^{*}$ & $0.062(0.018)^{* * *}$ & $0.069(0.042)^{*}$ \\
\hline Married & - & $-0.107(0.037)^{* * *}$ & - & $-0.108(0.037)^{* * * *}$ \\
\hline No confession & - & $0.075(0.033)^{* *}$ & - & $0.076(0.033)^{* *}$ \\
\hline \multicolumn{5}{|l|}{$\begin{array}{l}\text { Peer, family and sub- } \\
\text { cultural influence }\end{array}$} \\
\hline $\begin{array}{r}\text { Has more than } 20 \\
\text { friends }\end{array}$ & - & $0.062(0.030)^{* *}$ & - & $0.059(0.030)^{* *}$ \\
\hline $\begin{array}{l}\text { Criminal record of } \\
\text { parents or siblings }\end{array}$ & - & $0.183(0.071)^{* * *}$ & - & $0.197(0.070)^{* * *}$ \\
\hline $\begin{array}{r}\text { Parents divorced or } \\
\text { separated }\end{array}$ & $0.091(0.036)^{* *}$ & $0.054(0.051)$ & $0.103(0.036)^{* * *}$ & - \\
\hline$\rho$ & \multicolumn{2}{|c|}{$-0.673(0.215)$} & \multicolumn{2}{|c|}{$-0.690(0.207)$} \\
\hline $\begin{array}{l}\text { Likelihood-ratio test } \\
\text { of } \rho=0 \quad(p \text {-value ) }\end{array}$ & \multicolumn{2}{|c|}{$\begin{array}{c}3.790 \\
(0.052)^{*}\end{array}$} & \multicolumn{2}{|c|}{$\begin{array}{c}4.251 \\
(0.039)^{* *}\end{array}$} \\
\hline Log-Likelihood & \multicolumn{2}{|c|}{-737.08} & \multicolumn{2}{|c|}{-738.10} \\
\hline $\begin{array}{l}\text { Number of } \\
\text { observations }\end{array}$ & \multicolumn{2}{|c|}{960} & \multicolumn{2}{|c|}{960} \\
\hline
\end{tabular}

Notes: Standard errors in parentheses; $\left.{ }^{* * *}\right),{ }^{* *}$ ) and $\left.{ }^{*}\right)$ represent significance at the 1,5 and 10 percent level, respectively; significance of rho is tested using a likelihood-ratio test. Marginal effects are obtained as average partial effects, standard errors are computed using the delta method. See Table 1 for data. 